\author{
UNIVERSIDADE DE SÃO PAULO \\ FACULDADE DE ECONOMIA, ADMINISTRAÇÃO E CONTABILIDADE \\ DEPARTAMENTO DE ECONOMIA \\ PROGRAMA DE PÓS-GRADUAÇÃO EM ECONOMIA
}

João Victor Sales Marcolin

\title{
Commodity price shocks and the victory of Jair Bolsonaro in the 2018 presidential elections in Brazil
}

Choques em preços de commodities e a vitória de Jair Bolsonaro nas eleições presidenciais brasileiras de 2018

São Paulo 
Prof. Dr. Vahan Agopyan

Reitor da Universidade de São Paulo

Prof. Dr. Fábio Frezatti

Diretor da Faculdade de Economia, Administração e Contabilidade

Prof. Dr. José Carlos de Souza Santos

Chefe do Departamento de Economia

Prof. Dr. Wilfredo Fernando Leiva Maldonado

Coordenador do Programa de Pós-Graduação em Economia 
João Victor Sales Marcolin

\section{Commodity price shocks and the victory of Jair Bolsonaro in the 2018 presidential elections in Brazil}

Choques em preços de commodities e a vitória de Jair Bolsonaro nas eleições presidenciais brasileiras de 2018

Dissertação apresentada ao Programa de PósGraduação em Economia do Departamento de Economia da Faculdade de Economia, Administração e Contabilidade da Universidade de São Paulo, como requisito parcial para a obtenção do título de Mestre em Ciências.

Orientadora: Laura B. de Carvalho

\section{Versão Corrigida}

(versão original disponível na Biblioteca da Faculdade de Economia, Administração e Contabilidade)

São Paulo 
Marcolin, João V. S.

Commodity price shocks and the victory of Jair Bolsonaro in the 2018 presidential elections in Brazil / João Victor Sales Marcolin. - São Paulo, 2021. $44 p$.

Dissertação (Mestrado) - Universidade de São Paulo, 2021. Orientadora: Laura B. de Carvalho.

1. Political economy. 2. Crisis. 3. Elections. 4. Commodities. 5. Trade shocks. I. Universidade de São Paulo. Faculdade de Economia, Administração e Contabilidade. II. Título. 
João Victor Sales Marcolin

\section{Commodity price shocks and the victory of Jair Bolsonaro in the 2018 presidential elections in Brazil}

Choques em preços de commodities e a vitória de Jair Bolsonaro nas eleições presidenciais brasileiras de 2018

Dissertação apresentada ao Programa de PósGraduação em Economia do Departamento de Economia da Faculdade de Economia, Administração e Contabilidade da Universidade de São Paulo, como requisito parcial para a obtenção do título de Mestre em Ciências.

Laura B. de Carvalho

IPE-USP

Profa. Dra. Daniela Campello

EBAPE - FGV

Prof. Dr. Luís Meloni

IPE - USP

Prof. Dr. Gabriel Ulyssea

Drayton House - UCL

São Paulo

2021 



\section{Acknowledgements}

The completion of a research project is always challenging, and I am very grateful to the unwavering support of both my parents, Cláudio and Rejane, and of my partner José during all the academic trajectory that led me to this point. I will never know if I could have done it by myself, but I do know that they are the main reasons behind the joy I've found even in the face of these turbulent times. Speaking of joy, I would also like to extend my thanks to a long list of friends that have helped me along the way, but this would be far too tedious for the general reader. However, I do want to register a special thanks to my friends Matheus and Gustavo, as well as my siblings Maria Eduarda and Rodrigo.

Special thanks are also due to my adviser Laura Carvalho, who was always very supportive and patient. During my years at FEA, many people have been important to me, but I would like to give special thanks to professors Fernando Rugitsky, Gilberto Lima, Paula Pereda, Fabiana Rocha, Ariaster Chimeli and Laura Valladão. My colleagues and friends are far too many to cite everyone by name, but I would like to thank Débora Oliveira, Gabriel Monteiro, Gabriel Poveda, Pedro Marques and everyone at Made (FEAUSP Research Center on Macroeconomics of Inequalities) for all the help and for the comments on this dissertation. Of course, any mistakes and shortfalls that may remain in this final version are the sole responsibility of the author.

Last but not least, I would like to acknowledge that even the emotional support and intellectual work of all the people mentioned above (and also some people I've not mentioned) would not be sufficient for me to conclude this research project if it were not for the Brazilian public higher education system. I am especially indebted to the University of São Paulo for providing me a world-class education completely free of charge, even while the Brazilian public higher education has endured so many attacks and spending cuts. Also, this research received financial support from $\mathrm{CNPq}$ (Conselho Nacional de Desenvolvimento Científico e Tecnológico) and Fipe (Fundação Instituto de Pesquisas Econômicas). 


\section{Agradecimentos}

Completar um projeto de pesquisa é sempre um desafio, e eu sou muito grato ao apoio inabalável dos meus pais, Cláudio e Rejane, e do meu companheiro, José, durante toda a trajetória acadêmica que me trouxe até aqui. Eu nunca saberei se seria capaz ir tão longe sozinho, mas tenho certeza de que eles foram a principal razão da alegria que pude encontrar mesmo no meio destes tempos turbulentos. Falando em alegria, eu também gostaria de agradecer uma longa lista de amigos e amigas que me ajudaram durante o percurso, mas fazê-lo seria tedioso demais para o leitor comum. Entretanto, quero registrar um agradecimento especial aos meus amigos Matheus e Gustavo, e aos meus irmãos Maria Eduarda e Rodrigo.

Um agradecimento especial também é devido à minha orientadora, Laura Carvalho, que sempre me apoiou com atenção e paciência. Durante meus anos na FEA, muitas pessoas foram importantes na minha formação, mas gostaria de agradecer especialmente aos professores Fernando Rugitsky, Gilberto Lima e Ariaster Chimeli, bem como às professoras Paula Pereda, Fabiana Rocha e Laura Valladão. Entre colegas e amizades, a lista é demasiado grande para citar todos os nomes, mas eu gostaria de agradecer Débora Oliveira, Gabriel Monteiro, Gabriel Poveda, Pedro Marques e o pessoal do Made (Centro de Pesquisa em Macroeconomia das Desigualdades) por toda a ajuda e pelos comentários sobre o presente trabalho. Evidentemente, quaisquer erros e deficiências que restem nesta versão final são de minha responsabilidade exclusiva.

Por último, mas não menos importante, eu gostaria de reconhecer que todo o apoio emocional e o trabalho intelectual das pessoas mencionadas acima (entre outras pessoas que não mencionei) não seriam suficientes para a conclusão desta pesquisa se não fosse o sistema público de educação superior do Brasil. Estou em dívida especialmente com a Universidade de São Paulo, que me proporcionou a oportunidade de ter acesso a uma excelente educação totalmente gratuita, mesmo durante uma época de ataques às universidades públicas e cortes de financiamento à pesquisa. Aliás, a presente dissertação contou com o apoio financeiro do CNPq (Conselho Nacional de Desenvolvimento Científico e Tecnológico) e da Fipe (Fundação Instituto de Pesquisas Econômicas). 


\begin{abstract}
The ascension of far-right politicians and parties over the recent years has motivated research that set out to explain this trend as a consequence of economic variables. This research contributes to this debate by investigating the effect of negative shocks on the commodity trade on the support for Jair Bolsonaro in the Brazilian presidential election of 2018. First, we create a variable that measures the exposure of a given municipality to variation in international commodity prices. Then, we show that a fall in international commodity prices is associated with job loss in the commodity-producing sectors, and that a one-percent reduction in employment in commodity production is associated with an increase in Bolsonaro's share of votes: 0.078 percentage point in the first round and 0.076 percentage point in the runoff. However, these results are not robust to the inclusion of the share of self-declared pentecostal evangelicals in the population. This suggests an interaction between economic anxiety and shifts in cultural values, in consonance with the literature on the ascension of the far-right in other countries.
\end{abstract}

Keywords: Political Economy, Crisis, Elections. 


\section{Resumo}

A ascensão de políticos e partidos de extrema direita nos últimos anos tem motivado pesquisas que buscam explicar esta tendência a partir de variáveis econômicas. Esta pesquisa contribui com o debate ao investigar o efeito de choques negativos no comércio internacional de commodities sobre o apoio a Jair Bolsonaro na eleição presidencial de 2018. Primeiro, nós construímos uma variável que mede a exposição de um dado município a variações nos preços internacionais de commodities. Depois, mostramos que uma queda nos preços internacionais de commodities está associada a uma redução dos empregos em setores produtores de commodities, e que uma redução de $1 \%$ nos empregos produtores de commodities está associada a um aumento da parcela de votos de Bolsonaro: de 0.078 pontos percentuais no primeiro turno e 0.076 pontos percentuais no segundo turno. Entretanto, estes resultados não são robustos à inclusão da parcela de auto-declarados evangélicos pentecostais na população. Isto sugere uma interação entre ansiedade econômica e mudanças em valores culturais, em consonância com a literatura sobre a ascensão da extrema direita em outros países.

Palavras-chave: Economia Política, Crise, Eleições. 
Summary

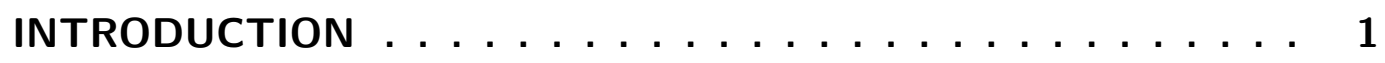

2 LINKING ECONOMIC CHANGES, CULTURAL GRIEVANCES AND POLITICAL OUTCOMES . . . . . . . . . . . . 3

3 MEASURING LOCAL EXPOSURE TO COMMODITY PRICE

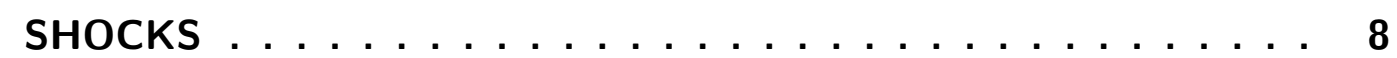

$3.1 \quad$ Research Design $\ldots \ldots \ldots \ldots \ldots \ldots$

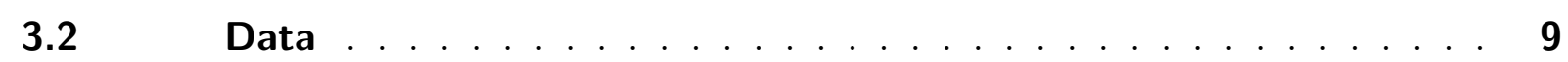

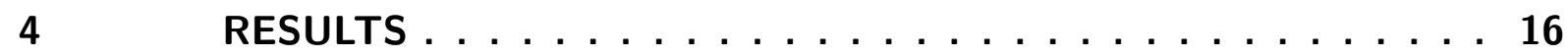

$4.1 \quad$ First stage results $\ldots \ldots \ldots \ldots \ldots \ldots$

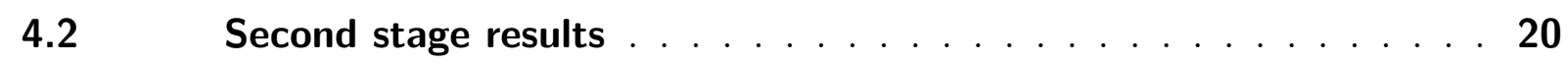

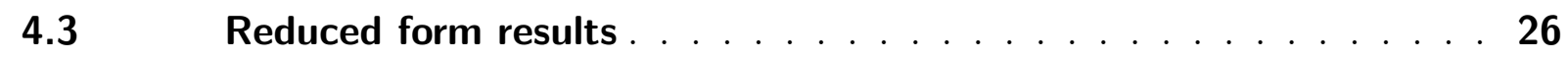

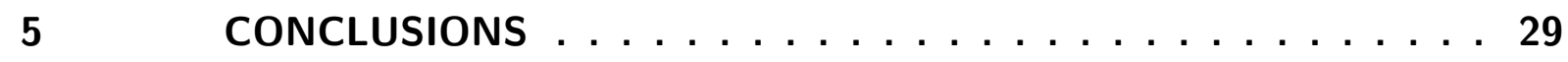

Appendices . . . . . . . . . . . . . 37

Appendix A COMMODITY PRICE TRAJECTORIES, 2010-2018 37

Appendix B SPATIAL VISUALIZATION OF ELECTION RESULTS 41 


\section{List of Figures}

Figure 1 - Spatial distribution of commodity price shocks, 2014-2018 . . . . . . . 12

Figure 2 - Specification chart: effect of z on delta\%_w, 1 control . . . . . . . 18

Figure 3 - Specification chart: effect of z on delta\%_emp, 1 control . . . . . . 18

Figure 4 - Specification chart: effect of z on delta\%_total_emp, 1 control . . . . 19

Figure 5 - Specification chart: effect of delta\%_emp on votes_PSL_1, 1 control . 22

Figure 6 - Specification chart: effect of delta\%_emp on votes_PSL_2, 1 control . 22

Figure 7 - Specification chart: effect of delta\%_emp on invalid_votes_1, 1 control 23

Figure 8 - Specification chart: effect of delta\%_emp on invalid_votes_2, 1 control 23

Figure 9 - Specification chart: direct effect of $\mathrm{z}$ on votes_PSL_1, 1 control . . . . 27

Figure 10 - Specification chart: direct effect of $z$ on votes_PSL_2, 1 control . . . . 27

Figure 11 - Specification chart: direct effect of $\mathrm{z}$ on invalid_votes_1, 1 control . . . 28

Figure 12 - Specification chart: direct effect of $\mathrm{z}$ on invalid_votes_2, 1 control . . . 28

Figure 17 - Spatial distribution of Bolsonaro's votes, first round 2018 . . . . . . . . 41

Figure 18 - Spatial distribution of Bolsonaro's votes, 2018 runoff . . . . . . . . . . 42

Figure 19 - Spatial distribution of invalid votes, first round 2018 . . . . . . . . . . 43

Figure 20 - Spatial distribution of invalid votes, 2018 runoff . . . . . . . . . . . . 44 


\section{List of Tables}

Table 1 - Compatibilization of commodity classifications . . . . . . . . . . . . 11

Table 2 - Datafolha poll on voter intentions, October $42018 \ldots \ldots$. . . . . . 14

Table 3 - Descriptive Statistics . . . . . . . . . . . . . . 15

Table 4 - First Stage Regressions - no controls . . . . . . . . . . . . . . 17

Table 5 - IV Regressions - no controls . . . . . . . . . . . . . . . 20

Table 6 - IV Regressions - all controls . . . . . . . . . . . . . . . 25

Table 7 - RF Regressions - no controls . . . . . . . . . . . . 26 


\section{Introduction}

The ascension of the far-right and anti-establishment politician Jair Bolsonaro in 2018 was a watershed event in Brazilian politics. Since 1994, Brazilian presidential elections were dominated by the center-left Worker's Party (Partido dos Trabalhadores, PT) and the center-right Party of Brazilian Social Democracy (Partido da Social Democracia Brasileira, PSDB). Thus the election of Bolsonaro, who ran in the much smaller Social Liberal Party (Partido Social Liberal, PSL) and using a much more extremist rhetoric, represents a break with previous election cycles (Nicolau, 2020). Since his inauguration day, Bolsonaro's presidency has attacked the institutions responsible for monitoring and punishing deflorestation in the Amazon rainforest (Pereira et al., 2020), and the longstanding tradition of foreign policy pragmatism was scrapped (Vidigal and Bernal-Meza, 2020). This change of course cannot have been a surprise for his supporters, given the speeches Bolsonaro gave during his presidential campaign (Rossi, 2018; Wallace, 2018).

Besides these more foreseable consequences of Bolsonaro's election, there is still the ongoing discussion concerning the president's direct responsability on the country's terrible response to the COVID-19 pandemic (Friedman, 2020; Fraser, 2020). For his resistence against the use of masks and efforts by local governments to implement social distancing measures (CNN, 2021), as well as his support for medicines with no efficacy in treating COVID-19 (Amorozo, Kos and Moreira, 2020), in 2020 the Senate began holding hearings to investigate the responsability of Bolsonaro's government on the high number of COVID-19 deaths in the country. Of course, this could not have been predicted prior to his election, but his government's attitudes concerning the environment and foreign policy were in fact major campaign topics and it begs the question of why such radical discourse was supported by a large part of the Brazilian electorate.

In this dissertation, we investigate if there is a link between economic anxiety and the election of Jair Bolsonaro in 2018 and set out to answer the question: did the 2014-16 economic crisis play a part in fostering support for Bolsonaro? Even though a lot has happened between PT's Dilma Rousseff's election in 2014 and Bolsonaro's election in 2018, including various corruption scandals and the impeachment of president Rousseff in 2016, one cannot help but wonder what was the impact of the economic variables in the ascension of Bolsonaro. His victorious presidential campaign in 2018 followed the second most intense and the longest crisis in the country's history. According to CODACE (2017), this recession lasted 11 quarters, from the second quarter of 2014 to the fourth quarter of 2016, and GDP fell 8.6\% throughout the period. In order to evaluate to what extent the crisis may have helped Bolsonaro's prospects, we turn to the recent literature on the ascension of anti-establishment politicians worldwide. 
Abroad, the election of Donald Trump and the Brexit referendum in 2016 have renewed the interest in research that sets out to explain why anti-establishment politicians and parties have enjoyed increased popular support in recent years. As we discuss in the following section, most papers attribute the surge in support for anti-establishment politicans to at least one of the following reasons: high unemployment; the decline of local industries as a consequence of increased international competition; higher competition over increasingly scarce public social spending; cultural conservatism; and demographic characteristics (Autor et al., 2020; Fetzer, 2019; Gidron and Mijs, 2019; Green and McElwee, 2019; Inglehart and Norris, 2016). This literature provides evidence that contexts of economic insecurity (high unemployment, welfare cuts or falling wages) are fertile grounds for anti-establishment politicians, who capitalize in a general feeling of dissatisfaction with the status quo.

However, most papers exploring the causes of the rise of anti-establishment politicians are focused in Western Europe or the USA. In order to assess the role of the recent crisis in Bolsonaro's 2018 election, we exploit the fact that part of the Brazilian crisis was the result of changes in the international commodity trade. First, we create a variable that measures the exposure of a given municipality to variation in international commodity prices. Assuming that Brazil can be considered a small country with no influence on commodity prices, this variable captures exogenous shocks to local economic conditions.

Then, on the first stage we exploit variation in the exposure to the negative trade shocks of the 2010s to show that a fall in international commodity prices causes job loss in the commodity-producing sectors. Since some municipalities are more reliant in the production of commodities than others, on the second stage we proceed to investigate if the job loss that is caused by an exogenous shock on the commodity trade affects the share of votes for Bolsonaro in both rounds of the 2018 election. Since the international literature is often interested in the effects of economic conditions on abstention, we also look for effects of job loss on the share of invalid votes - voting is mandatory in Brazil, but some voters don't choose a candidate and cast "invalid votes" that do not count.

Our results indicate that negative trade shocks are associated with the support for Bolsonaro (both in the first round and in the run-off) and with a decrease in the share of invalid votes (only in the first round) of the 2018 presidential election. However, these results are not robust to the inclusion of the share of self-declared pentecostal evangelicals in the population. This suggests that religiosity may explain a relevant part of Bolsonaro's vote share. 


\section{Linking economic changes, cultural grievances and political out- comes}

The recent surge in support for anti-establishment politicians and parties is a multi-dimensional phenomenon. As discussed by Muis and Immerzeel (2017) and Inglehart and Norris (2016), there is the supply side of party strategies and there is the demand side of public opinion. On the supply side, researchers wonder what motivates a party or a politician to radicalize. On the demand side, the discussion revolves around the causes of public support for anti-establishment candidates or movements. Inglehart and Norris (2016) also review the literature on the role of electoral rules in facilitating or hampering the rise of such parties.

On the demand side, there are broadly two approaches to explain what drives the public to support anti-establishment politicians. On the one hand, some papers focus on contexts of economic anxiety and deterioration of material circumstances as the main drive behind dissatisfaction with establishment politics. On the other hand, some papers focus on the role of cultural backlash movements, as a reaction to cosmopolitan and progressive values such as affirmative actions and leniency with immigration. As discussed by Inglehart and Norris (2016), this distinction between economic and cultural factors is somewhat artificial, as economic insecurity can fuel the feeling of being left behind, which is so often a motivation for backlash against progressive cultural change.

Keeping this in mind, we explore the literature on possible explanations for the support of anti-establishment politicians without delving into the question of what leads a politician or a party to posit itself as anti-establishment. Our goal is to enumerate some mechanisms that have been observed abroad and may be behind Bolsonaro's election in 2018. We also provide an assessment of the various empirical approaches applied to the question of explaining the recent surge in support for anti-establishment politicians.

Examining the effect of trade shocks, Autor et al. (2020), Colantone and Stanig (2018a, 2018b) and Dippel, Gold and Heblich (2015) provide evidence that regions that host industries facing direct competition from China show an increase in support for anti-establishment politicians. They use the local share of employment in those sectors to assess a given region's exposure to Chinese competition, and argue that workers react to the deterioration of local job markets by increasing the support for nativist and xenophobic politicians.

These papers explore the radicalization of the electorate in the US (Autor et al., 2020), Western Europe (Colantone and Stanig, 2018a) and Germany (Dippel, Gold and Heblich, 2015) by regressing the share of votes for radical politicians on a measure of 
exposure to competition from Chinese imports. They argue that regions more affected by international competition become more polarized and tend to support far-right politicians. The empirical strategy is based on Bartik shocks, and lingers on the assumption that the increase in Chinese imports in other countries is exogenous to changes in local demand for imports and derives solely from increased Chinese industrial competitivity. Thus, they instrument the increase in imports in their regions of interest by the increase in imports in other countries. Colantone and Stanig (2018b) employ the same empirical strategy, but to explain the share of votes for Leave in the Brexit referendum. Our empirical strategy is very similar to the above, except that we focus on the effect of commodity price shocks and not increased industrial competition. We consider that the higher the proportion of people employed in the production of commodities, the higher the exposure of a given municipality to shocks in commodity prices.

The importance of the local productive structure as a mediator between economic anxiety and political dissatisfaction is also stressed in the work of Becker, Fetzer and Novy (2017) and Alabrese, Becker, Fetzer and Novy (2019). They employ machine learning models that are not adequate for causal inference, but provide valuable insights into interesting correlations. They find that in the context of the Brexit referendum, short-term changes such as tax cuts and temporary increases in immigration are associated with higher support for Brexit only in regions with high shares of low-paying, low-qualification jobs.

Carreras, Carreras, and Bowler (2019), also investigating the Brexit referendum, argue that this relation between economic foundations and political dissatisfaction is particularly strong in regions that have been experiencing a long-term decline relative to other regions of the country. They work with panel data, and their underlying assumption is that age, gender, education and social class are exogenous to long-term deterioration in economic conditions, which is problematic if social mobility is high or if individuals incorporate future earnings prospects when deciding which level of education to attain. Despite these problems, the importance of long-term trends in building up political dissatisfaction is also stressed by Rodrik (2018), based on a qualitative analysis of economic history and theoretical results.

Besides these discussions about the local impacts of globalization, there is some evidence on the impacts of domestic policy. Prominently, there is evidence that restricting access to social welfare increases the support for anti-establishment political parties, as shown by Fetzer (2019) in the case of the rise of UKIP (UK Independence Party) and Brexit, and by Cavaille and Ferwerda (2017) in the case of the increase in support for Austria's Freedom Party.

It would be very interesting to investigate the effect of the austerity measures implemented in Brazil after 2015 in building up political dissatisfaction. However, due to 
data limitations, it does not seem possible to conduct a research such as Fetzer (2019) for Brazil. His method relies on detailed data on the distribution of social benefits claimants, and a clear set of rules that reduce government spending on social benefits, which provide a quasi-experimental design. Cavaille and Ferwerda (2017) also take advantage of a quasiexperimental context: in 2006, an EU legal directive forced Austrian municipalities to open public housing to foreign residents, exogenously increasing the demand for a benefit that has a fixed supply on the short term.

Moreover, other papers provide evidence that job or income losses result in higher support to far-right parties in Sweden (Dehdari, 2018) and far-left parties in the Netherlands (Gidron and Mijs, 2019), even when this context isn't directly driven by domestic policy. Dehdari (2018) employs Bartik shocks to instrument local job loss by national trends, and Gidron and Mijs (2019) use a panel of individual-level data for the period 2007-2015.

Fortunately, our option to focus on international conditions as a source of exogenous variation in local economic prospects has already been successfully used to study election results in Latin America and in Brazil. In particular, Campello and Zucco (2016) create a Good Economic Times (GET) index that combines commodity prices and US interest rates into a one-dimensional indicator, taking advantage of the exogeneity of such variables in a Latin American context. They show that in low-savings-commodity-exporting countries of Latin America, good international conditions tend to increase support for the incumbent, while unfavorable international conditions do the opposite. However, this research does not focus in election outcomes in a single country, but in average effects on a panel of countries. Also focusing on Brazil, Novaes and Shiumerini (2015) also find evidence that negative shocks in the price of agricultural commodities erodes the support for the incumbent, though their analysis is entirely at the municipal level and is focused on the re-election prospects of incumbent mayors.

Our main contribution to the aforementioned literature is that we analyze a specific election that is recognized as a turning point in the Brazilian political system. We show that worsening economic conditions played a part in building support for an anti-establishment politician, in Brazil as in elsewhere, and we do this by exploiting exogenous variation in economic conditions due to shocks in the international trade of commodities.

This is not to say that the electorate took international trade conditions explicitly into account when choosing a candidate in the 2018 election. As discussed by Campello and Zucco (2016), there is good reason to believe that voters aren't able to distinguish competence from chance when assessing government's management of the economy. Voters may attribute the worsening economic conditions to mismanagement or corruption, for instance. This means that the fact that international trade was not a main topic in the election doesn't invalidate our results, as long as the trade shocks are, in fact, an exogenous source of variation in local economic conditions. 
It is widely recognized that the corruption scandals uncovered by the Car Wash operation took a major toll in the Workers' Party electoral prospects and fomented antiestablishment movements and demonstrations (Hunter and Power, 2019). Due to extensive media coverage, all Brazilian municipalities were exposed to the corruption scandals, so it doesn't appear that we could isolate the effect of the corruption scandals in the results of the election.

Besides the aforementioned papers that look into the effect of economic conditions on anti-establishment support, there are also papers that look into cultural factors. These papers are not able to identify plausibly exogenous shifts in cultural values, but provide useful insights into the relations between demographic characteristics of the population, public opinion, and support for anti-establishment politicians.

Notably, Inglehart and Norris (2016) use individual-level data from the European Social Survey for the period 2002-2014 to compare how well economic variables or cultural values indicators predict voting for populist parties (defined as anti-establishment, authoritarian and nativist parties). They work with five different groups of regressors and find that the regression specification that only takes into account demographic variables and cultural values indicators is the most parcimonious predictive model of voting for anti-establishment politicans or parties.

Again, this method does not allow for causal identification, but it is interesting that they find that anti-immigrant attitudes, mistrust of global or national governance and support for authoritarian values are major predictors of the vote for populist parties. Also, the analysis of the various specifications discussed by Inglehart and Norris (2016) confirms that populist support is greatest among older people, men, the less educated, people who belong to their country's ethnic majority, and the religious.

Inglehart and Norris' (2016) finding that the religious are more likely to support anti-establishment politicians provides an interesting relation with the Brazilian case, where recent years saw a surge in right-wing evangelical candidates for Congress, who use a moralistic platform to advocate for conservative values (Quadros and Madeira, 2018). The support of evangelical politicians for Bolsonaro is well-documented by Almeida (2019). For context, it is worth mentioning that Brazil is a predominantly catholic country, but the number of self-declared evangelicals has risen steadily in the last years. According to Census data, $22.16 \%$ of Brazilians belonged to evangelical churches in 2010, up from $15.41 \%$ in 2000 . In the same period, the proportion of catholics went from $73.57 \%$ to $64.62 \%$.

Some other papers use methods similar to Inglehart and Norris' (2016) and provide additional evidence in line with their findings. Arnorsson and Zoega (2018) analyze the Brexit referendum and find that British regions with lower GDP per capita, a higher shares of older people, lower levels of education and high net immigration are regions 
where people are more likely to be suspicious of immigrants and vote for Brexit. Analyzing the election of Donald Trump in 2016, Green and McElwee (2019) find that cultural values regarding race are good predictors of white voters' choice, whereas minority voters' choices are best predicted by economic indicators.

Therefore, while cultural values are certainly very important to the recent surge in the suport for anti-establishment politicians, there is evidence that the economic context is paramount to create a context in which people mobilize in defense of such values (Fetzer, 2019; Carreras, Carreras and Bowler, 2019; Cavaille and Ferwerda, 2017; Dehdari, 2018). Unfortunately, not many papers look into the relation between economic distress and cultural values in Brazilian elections. Notably, Barros and Santos Silva (2019) use Bartik shocks to look into labor market shocks as a way to explain Bolsonaro's ascension to power, and they find out that male-specific labor demand shocks increase support for Bolsonaro, while female-specific labor demand shocks decrease support for Bolsonaro. They hypothesize that when facing economic problems men feel more compelled to vote for a reactionary candidate, whereas women feel more compelled to vote for a more pro-social platform. They also look into race-specific labor demand shocks, but do not find any significant difference between white and black voters.

In the light of this, we chose to explore variation in exposure to commodity price shocks as a way to isolate part of the effect of the crisis in the support for Bolsonaro specifically, the part of the crisis that can be attributed to negative trade shocks. Depending on the sectoral composition of employment, some municipalities are more affected by trade shocks than others. Assuming that Brazil can be considered a small country in the international trade of commodities, variation of commodity prices is exogenous to domestic policies, and we can identify the effect of negative trade shocks in electoral results. This allows us to investigate whether a deterioration in economic conditions due to trade shocks provides a fertile ground for support for Bolsonaro's anti-establishment platform. We also include demographic controls in order to check whether race, education, gender, religion and other variables are important mediators between this exogenous economic shock and electoral outcomes such as the support for Bolsonaro and the share of invalid votes. 


\section{Measuring local exposure to commodity price shocks}

\subsection{Research Design}

Our interest lies in two electoral results from each round of the 2018 presidential election: the share of votes for Bolsonaro's PSL and the share of invalid votes. For each of these variables (hereafter "y"), we estimate an IV equation of the form:

$$
y_{i}=\gamma+\beta x_{i}+\lambda \operatorname{controls}_{i}+\epsilon_{i}
$$

In the expression above, $x$ is a measure of job loss due to international price shocks in the commodity trade. Since the local economic shock can reflect previous government policies to support the commodity-export sector, $x$ may be endogenous to political preferences. We therefore use an instrument that captures only the exogenous part of the variation in economic conditions.

Our approach is based on the work by Autor et al. (2020), and we use Bartik shocks to measure differential exposure to commodity price shocks across Brazilian municipalities. For each municipality $i$, the exposure to shocks in the international trade of commodities is the average change in the international price of commodity $j$ weighted by the share of commodity $j$ 's production in $i$ 's employment:

$$
z_{i}=\sum_{j} \frac{L_{i j}}{L_{i}} \frac{\Delta P_{j}}{P_{j 0}}
$$

In the expression above, $\Delta P_{j}$ is the variation of the international price of commodity $j$ between the election year and the year of the previous election, 2014. $P_{j 0}$ is the international price of commodity $j$ in 2014, and $L_{i j} / L_{i}$ stands for the share of sector $j$ in the total employment of the municipality $i$ in the year 2010. We chose a year previous to the shock so that the municipalities' sectoral composition of employment isn't endogenous to the price shocks of 2014-2018.

If Brazil is a small country with no market power in the commodity trade, then variations in commodities' prices have no relation to domestic policy, and this instrument captures the exogenous part of $x$ 's variation. Thus, using $z$ as an instrument for $x$ allows us to identify the causal effect of trade shocks on local political outcomes. The first stage equation takes the form:

$$
x_{i}=\gamma_{1}+\beta_{1} z_{i}+\lambda_{1} \text { controls }_{i}+\epsilon_{1 i}
$$


The causal mechanism we investigate is the following: an international shock that decreases the price of commodities produced in a given municipality leads to job losses. This economic adversity will foster political dissatisfaction amongst voters, who may feel inclined to vote on the anti-establishment candidate or nullify their vote. If this description is accurate, municipalities that produce commodities whose prices dropped will show higher support for Bolsonaro or a higher share of invalid votes.

In both the first and second stages, we include a set of controls that accounts for demographic, social and economic conditions of the municipalities. We present and discuss these controls in the following section.

\subsection{Data}

Since our dependent variables are electoral outcomes, we use data from the Superior Electoral Court (TSE, 2018) concerning the presidential election of 2018 at the municipality level. This data comprises the vote share of Bolsonaro's PSL in both rounds of the presidential election, as well as the share of invalid votes. The four dependent variables are the following:

- votes_PSL_1: share of votes for Bolsonaro's PSL on the first round;

- votes_PSL_2: share of votes for Bolsonaro's PSL on the runoff;

- invalid_votes_1: share of invalid votes on the first round;

- invalid_votes_2: share of invalid votes on the second runoff.

In Brazil, presidential elections happen once every four years in a two-round system. In the first round, that usually happens in the first weekend of October, there are multiple candidates. If any of them manages to get an absolute majority (50\% plus one vote), then that candidate is elected. If not, there is a runoff between the two candidates with the most votes, which usually happens three or four weeks after the first round. Voting is mandatory for anyone over 18 and under 70 years old, and voters that abstain have to pay a small fee, and yet abstention levels have increased in recent years (Damé, 2018).

According to data from TSE (2018), 20.3\% of voters abstained in the first round of 2018, and $21.3 \%$ abstained in the runoff. This isn't very different from the previous election. In 2014, for instance, abstention was around $19.4 \%$ in the first round and $21.1 \%$ in the runoff. Even when voters do show up at the polling site, they might not chose a candidate and cast an invalid vote, that does not count. The share of invalid votes increased greatly in the runoff of 2018 when compared to 2014 : from $6.34 \%$ in 2014 to $9.59 \%$ in 2018 . So we chose to investigate whether that sign of crescent dissatisfaction with politics was due, at least in part, to job losses caused by negative trade shocks. 
The first round of the 2018 election happened in October 7, and Bolsonaro was the candidate with the most valid votes: $46.03 \%$. He was followed by PT's Fernando Haddad, with 29.28\%. The runoff between the two candidates happened in October 28, and Bolsonaro was elected with 55.13\%. In Appendix B, we provide figures that show the spatial distribution of Bolsonaro's votes, as well as the spatial distribution of invalid votes.

In order to calculate the variables $x$ and $z$ that are used to assess the impact of the trade shocks, we use data from the Relação Anual de Informações Sociais (RAIS) and from IMF's Primary Commodity Price System (PCPS). RAIS is essentially a yearly census of the Brazilian formal labor market, with data collected by the Ministry of the Economy. It records information on every formally employed worker, except for interns and domestic workers. With RAIS, we are able to calculate the share of each commodity-producing sector in the formal employment for each municipality, and we also have information on the average wage for each sector and municipality.

IMF's PCPS, on the other hand, records international price indexes for 103 commodities classified in accordance to the UN's Harmonized Commodity Description and Coding System (HS). Since RAIS' classification of economic activities isn't compatible with the HS, we propose a correspondence between RAIS' and IMF's commodity classifications, presented on Table 1. This allows us to combine RAIS' and PCPS' data in order to calculate $z$ using equation (2).

Using data from Comex Stat, a platform by the Ministry of the Economy that registers data on all Brazilian exports and is compatible with IMF's classification, the 21 commodities listed in Table 1 amounted to $44.2 \%$ of the value of all Brazilian exports in 2010. Throughout the 2010s, these commodities became even more important, amounting to $52.4 \%$ of the value of all Brazilian exports in 2018 .

In 2018, the production of these 21 commodity categories amounted to $3.7 \%$ of all formal employment in Brazil, according to RAIS. So we do not expect that international trade shocks are the main reason for economic anxiety throughout the country. However, since these sectors are relatively more important in some municipalities, we can exploit variation in the exposure to trade shocks across municipalities and estimate the effect of trade shocks on local electoral outcomes. The production of these commodities amounts to at least $5.1 \%$ of formal employment for half of Brazilian municipalities, and at least $12.6 \%$ of formal employment for a quarter of Brazilian municipalities.

In Table 3, we provide descriptive statistics on all the variables included in the dataset. For the moment, it is worth noting that the majority of Brazilian municipalities were exposed to negative trade shocks from 2014 to 2018, as measured by variable z (see Figure 1). This reflects the fact that the international price of most commodities included in our analysis fell during the period. Appendix A provides graphs of the price trajectory for each commodity for the period 2010-2018. 
Table 1 - Compatibilization of commodity classifications

\begin{tabular}{|c|c|}
\hline IMF's PCPS & RAIS \\
\hline Aluminum & Extração de minério de alumínio \\
\hline Bananas & $\begin{array}{l}\text { Cultivo de frutas de lavoura } \\
\text { permanente, exceto laranja e uva }\end{array}$ \\
\hline Beef & Criação de bovinos \\
\hline Citrus fruit + orange juice & $\begin{array}{l}\text { Cultivo de uva } \\
\text { Cultivo de laranja }\end{array}$ \\
\hline Coal & Extração de carvão mineral \\
\hline Cocoa & Cultivo de cacau \\
\hline Coffee & $\begin{array}{l}\text { Cultivo de café } \\
\text { Cultivo de fumo }\end{array}$ \\
\hline Cotton & Cultivo de algodão herbáceo \\
\hline Crude oil & Extração de petróleo e gás natural \\
\hline \multirow[t]{4}{*}{ Fish } & Pesca em água salgada \\
\hline & Pesca em água doce \\
\hline & Aquicultura em água salgada \\
\hline & Aquicultura em água doce \\
\hline \multirow[t]{2}{*}{ Hardwood logs } & Produção florestal - florestas \\
\hline & Atividades de apoio à produção florestal \\
\hline Iron ore & Extração de minério de ferro \\
\hline Lamb & Criação de caprinos e ovinos \\
\hline Meat - DISTRIB & $\begin{array}{l}\text { Criação de outros animais de } \\
\text { grande porte }\end{array}$ \\
\hline Molybdenum & Extração de minério de manganês \\
\hline Poultry & Criação de aves \\
\hline Soybeans & Cultivo de soja \\
\hline Sugar & Cultivo de cana-de-açúcar \\
\hline Swine (Pork) & Criação de suínos \\
\hline & Extração de minério de estanho \\
\hline Vegetables (Tomato) & Horticultura \\
\hline
\end{tabular}

Note: PCPS' price index for Coffee also includes Tobacco, and the index for Molybdenum also includes Manganese. 
Figure 1 - Spatial distribution of commodity price shocks, 2014-2018

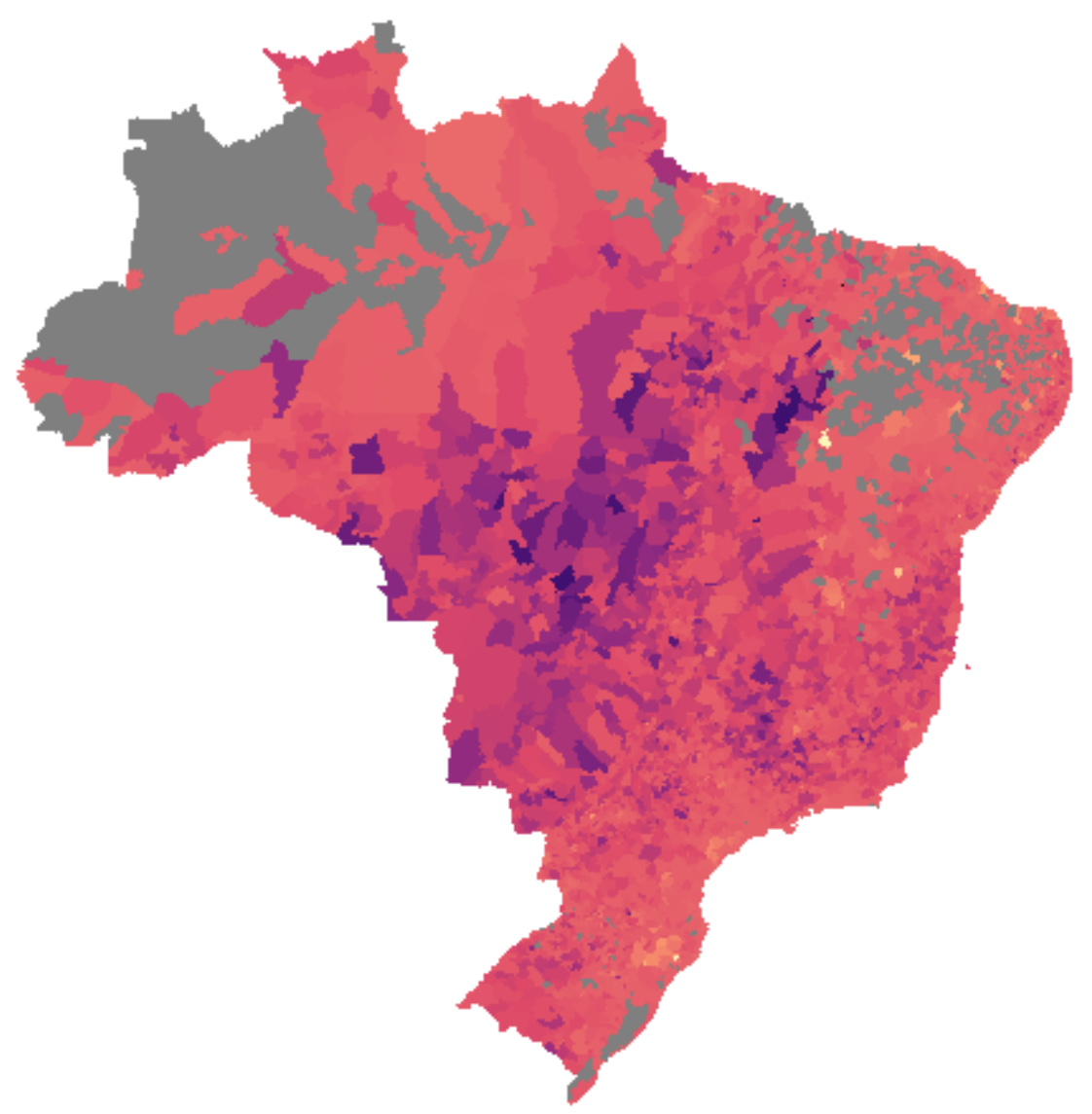

Figure 1 allows us to see that the majority of municipalities was subject to a negative commodity price shock and that municipalities in the Midwest were more impacted than those in other regions of the country. The areas in grey refer to municipalities for which we have no data on formal employment.

RAIS' data also allows us to calculate three measures of the impact of the commodity shock on the formal labor maket:

- delta\%_emp: the percentage change in employment in the commodity-producing sectors between 2014 and 2018;

- delta\%_total_emp: the percentage change in total employment (all sectors) between 2014 and 2018;

- delta\%_w: the percentage change in the average wage in the commodity-producing sectors between 2014 and 2018. 
We did not know which of these three measures would be most impacted by a commodity price shock and regarded it as an empirical question. The results that we discuss in the following section provide evidence that a negative shock in commodity prices will reduce the number of people employed in the commodity-producing sectors, thus affecting delta\%_emp. The average wage of those that keep their job does not appear to change. Also, total formal employment does not seem to change in response to a commodity price shock.

This suggests that negative price shocks cause job losses in the commodity-producing sectors but does not affect the wages of those that keep their jobs and does not lead to substantial job losses in other sectors not directly involved in commodity production. So we chose to use delta\%_emp as our variable $x$ when estimating equations (1) and (3).

As shown in Table 3, half of the municipalities for which data is available show a reduction in employment from 2014 to 2018. This is so both for commodity-producing sectors (delta\%_emp) and for all sectors (delta\%_total_emp). However, over half of the municipalities show an increase in the average wage of those who were able to keep their jobs in the commodity-producing sectors.

Finally, we also include some variables from the Census of 2010 to provide controls for some socio-economic and demographic characteristics of the municipalities, listed below:

- over10mw: \% of people with income above 10 mininum wages per month;

- white: \% of self-declared white people;

- men: \% of men;

- university: \% of people who've completed an undergraduate course;

- mean_income: mean monthly income per capita;

- log_pop: log of the municipality's population;

- 60_to_69_years: \% of people from 60 to 69 years old;

- evang_pente: \% of self-declared pentecostal evangelicals;

- north: dummy for municipalities that belong in the Northern region of Brazil;

- northeast: dummy for municipalities that belong in the Northeastern region of Brazil;

- midwest: dummy for municipalities that belong in the Midwestern region of Brazil;

- south: dummy for municipalities that belong in the Southern region of Brazil. 
As discussed by Nicolau (2020), these controls (except for the log of the population) are highly correlated with the propensity to support Bolsonaro in the election of 2018 . Bolsonaro won in all Southern and Southeastern states and lost in all Northeastern states. Electoral polls show his prevalence amongst white, richer, older and evangelical voters. Bolsonaro was also the candidate of choice for the majority of men and college-educated people. Table 3 includes descriptive statistics for all controls.

Bellow, Table 2 provides the results from Datafolha's October 4 poll on voter intentions, a few days before the first run of the 2018 presidential election (G1, 2018). It confirms that the preference for Bolsonaro is higher among men, evangelicals, the college-educated, people with higher income and white people. It also shows the regional disparity in voter intentions, with the Northeast showing much less support for Bolsonaro than the national average, while the South is the region that supported him the most. However, Datafolha's poll does not support the notion that the elderly were more likely to vote for Bolsonaro than the general electorate.

Table 2 - Datafolha poll on voter intentions, October 42018

\begin{tabular}{ll}
\hline Voter category & Bolsonaro's vote share \\
\hline \hline Total & $35 \%$ \\
White voters & $42 \%$ \\
Men & $42 \%$ \\
Voters with college degree & $44 \%$ \\
Voters with family income above 10 min. wages & $53 \%$ \\
Voters over 60 years old & $34 \%$ \\
Evangelical voters & $42 \%$ \\
Northern voters & $36 \%$ \\
Northeastern voters & $20 \%$ \\
Midwestern voters & $41 \%$ \\
Southern voters & $45 \%$ \\
Southeastern voters & $39 \%$ \\
\hline
\end{tabular}




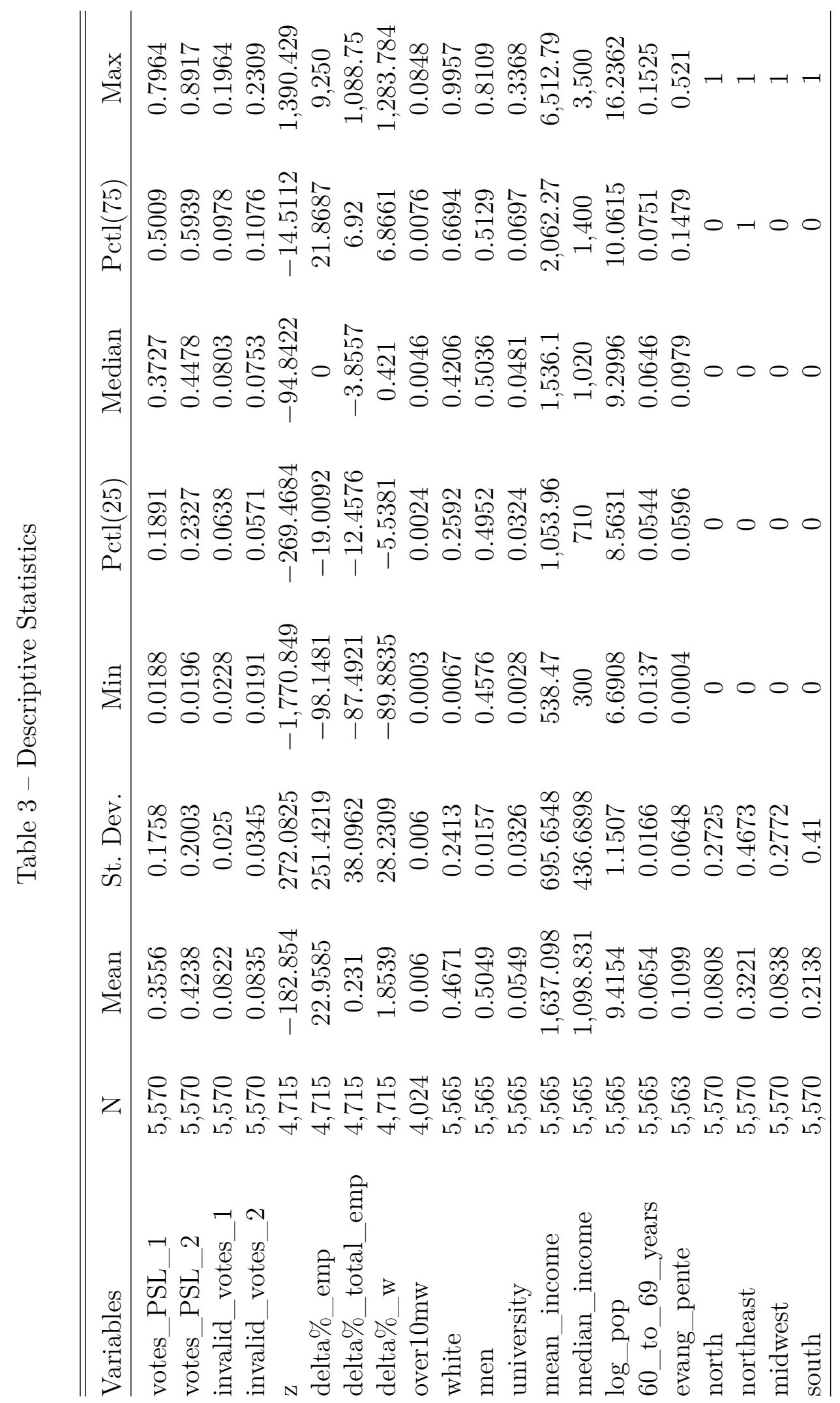




\section{Results}

In this section, we present our regression results. First we will look into the first stage results showing the relation between a commodity price shock and formal labor market indicators such as employment and the average wage in commodity-producing sectors. This allows us to establish that external shocks reducing commodity prices are associated with a reduction in the formal employment on commodity production. This might be a source of the sort of economic anxiety that provides a fertile ground for radical right candidates such as Jair Bolsonaro. We also explore the role of commodity price shocks in reducing the average wage of formal workers in the commodity-producing sectors or reducing formal employment in other sectors, but find no evidence of these effects for the analyzed period.

Then we will take a look into the second stage results that link the commodity price shocks to electoral outcomes, via the effects of a price shock in the local labor markets. We find that a commodity-shock induced job loss is associated with increased support for Bolsonaro in both rounds, though this result is not robust to the inclusion of the share of self-declared evangelicals. We also show that such job loss is associated with a decrease in the share of invalid votes in the first round, except in those specifications where we take into account the share of men or the log of the municipality's population.

After that, we discuss the reduced form estimates that explore the direct relationship between a price shock and electoral outcomes, without taking into account the mediation of a shock through the labor market. We show that the main results from the second stage regressions are reproduced: a negative commodity price shock is associated with an increase in the support for Bolsonaro in both rounds and with a decrease in the share of invalid votes in the first round. It is worth noting that the reduced form estimates are much more significant than the second stage estimates. This suggests that the effect of a price shock may be felt through some variable that isn't captured when we look at the change in formal jobs. For instance, informal jobs may be more affected by a negative commodity price shock. 


\subsection{First stage results}

Our first step is to investigate which of the formal labor market indicators we have built is most impacted by a commodity price shock. We regress each of the labor market outcome variables on $\mathrm{z}$, the commodity price shock variable. Table 4 , bellow, reports the estimated coefficients of $\mathrm{z}$ on the regressions that do not include any of the controls (we omit the constant). As we show in Figures 2, 3 and 4, the results are generally robust to the inclusion of any or all of the controls that we've discussed in section 3.2.

Table 4 - First Stage Regressions - no controls

\begin{tabular}{|c|c|c|c|}
\hline & \multicolumn{3}{|c|}{ Dependent variable: } \\
\hline & $\begin{array}{c}\text { delta\%_w } \\
\text { (1) }\end{array}$ & $\begin{array}{c}\operatorname{delta} \% \text { emp } \\
(2)\end{array}$ & $\begin{array}{c}\operatorname{delta} \% \text { _total_emp } \\
(3)\end{array}$ \\
\hline $\mathrm{Z}$ & $\begin{array}{c}0.00179 \\
(0.00112)\end{array}$ & $\begin{array}{c}0.03791^{* * *} \\
(0.00872)\end{array}$ & $\begin{array}{c}-0.00364^{*} \\
(0.00197)\end{array}$ \\
\hline Observations & 4,715 & 4,715 & 4,715 \\
\hline $\mathrm{R}^{2}$ & 0.00030 & 0.00168 & 0.00068 \\
\hline Adjusted $\mathrm{R}^{2}$ & 0.00009 & 0.00147 & 0.00046 \\
\hline Residual Std. Error & 28.22970 & 251.23680 & 38.08740 \\
\hline F Statistic & 1.40381 & $7.94594^{* * *}$ & $3.19276^{*}$ \\
\hline
\end{tabular}

Variable $\mathrm{z}$ is a weighted average of the change in the international prices of the commodities produced in each municipality. So an increase in $z_{i}$ is to be interpreted as an increase in the prices of the commodities produced in the municipality $i$. With that in mind, the results indicate that a positive commodity price shock does not have a significant impact on delta\%_w or delta\%_total_emp, but does increase delta\%_emp.

That is to say that a commodity price shock does not have a significant effect on the average wage of the people employed in the commodity production (delta\%_w), nor does it affect overall employment in a given municipality (delta\%_total_emp). However, a commodity price shock does affect the number of people directly employed in the commodity-producing sectors (delta\%_emp), with a good F statistic.

These results are highly robust to the inclusion of any (or all) of the controls that we've discussed in section 3.2, as shown in the specification charts bellow. Each chart plots how the coefficient of $\mathrm{z}$ changes as we include the controls one at a time. The coefficients are presented in decreasing order, and the estimated coefficient of $\mathrm{z}$ when we include all controls is marked in red. The dark bars around the point estimates give us the $5 \%$ confidence interval, while the lighter bar gives us the $1 \%$ confidence interval. 
Figure 2 - Specification chart: effect of $\mathrm{z}$ on delta\%_w, 1 control

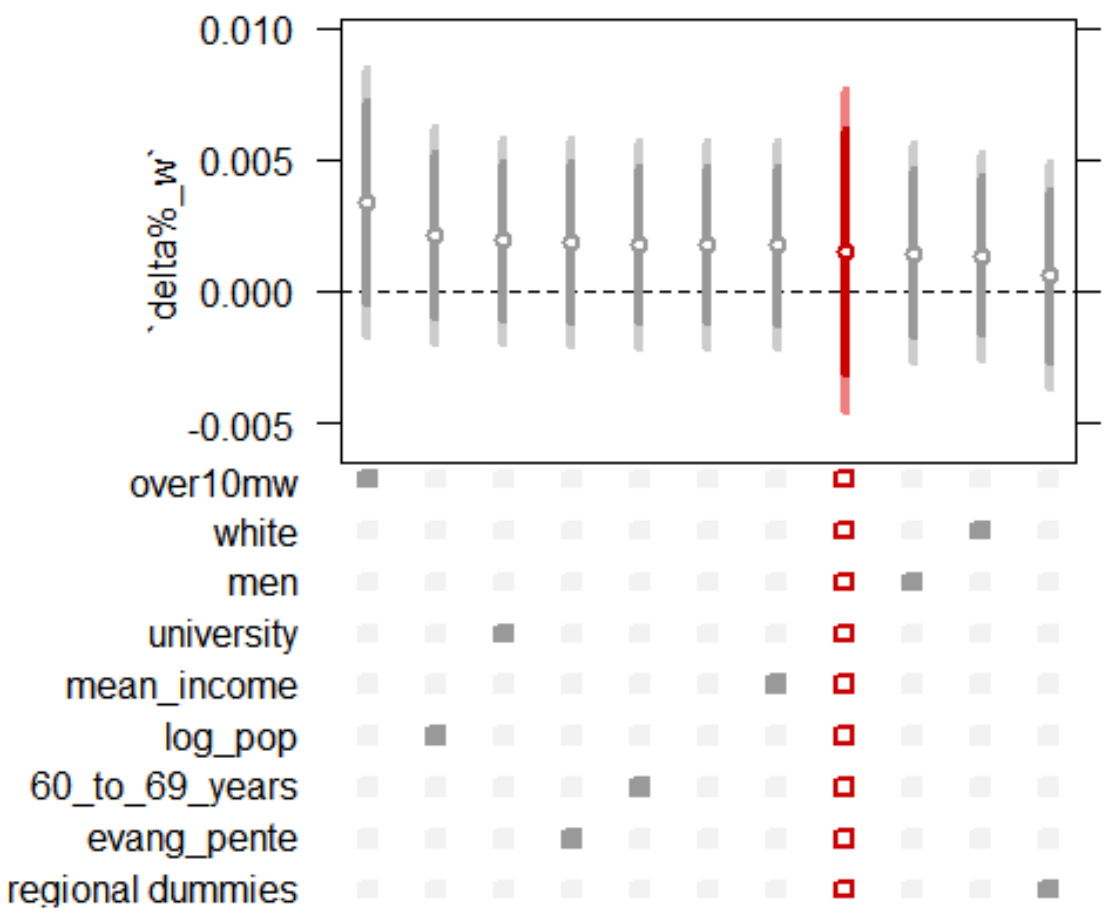

Figure 3 - Specification chart: effect of $\mathrm{z}$ on delta\%_emp, 1 control

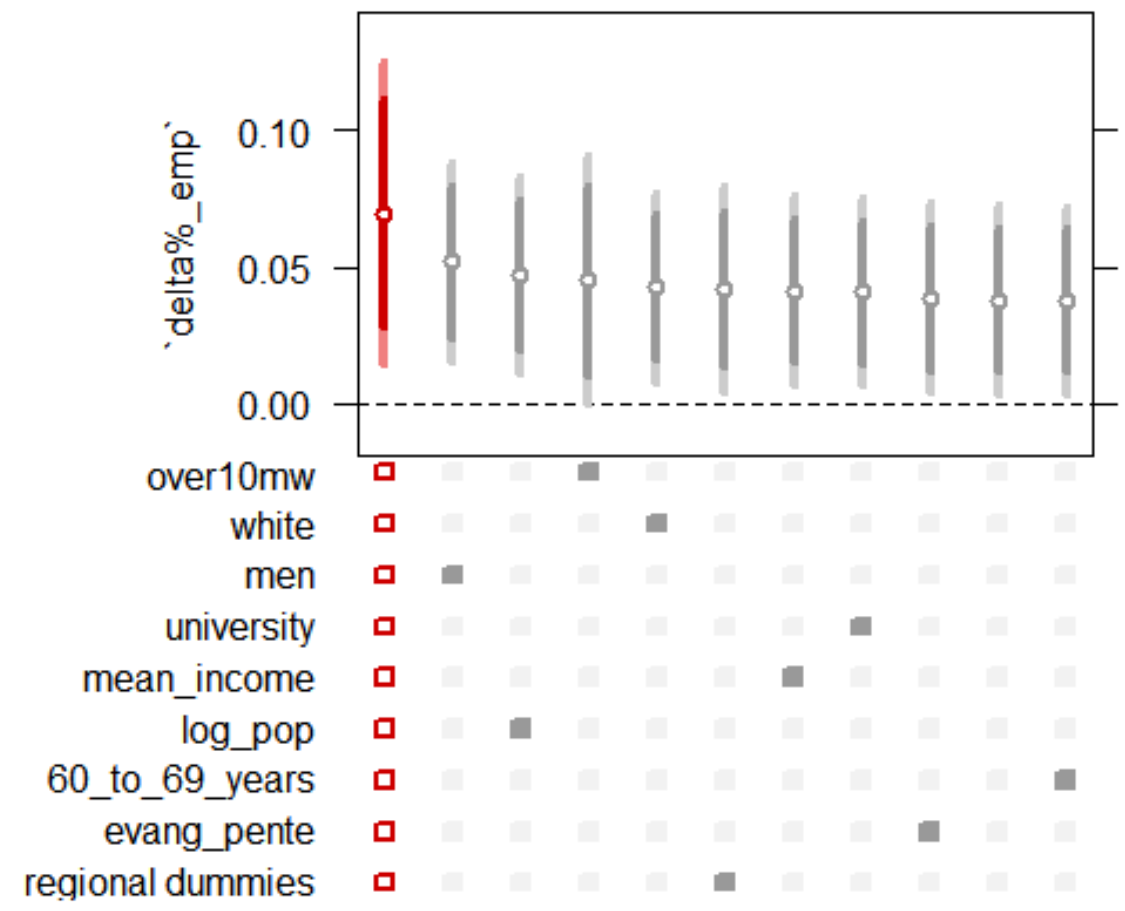


Figure 4 - Specification chart: effect of $\mathrm{z}$ on delta\%_total_emp, 1 control

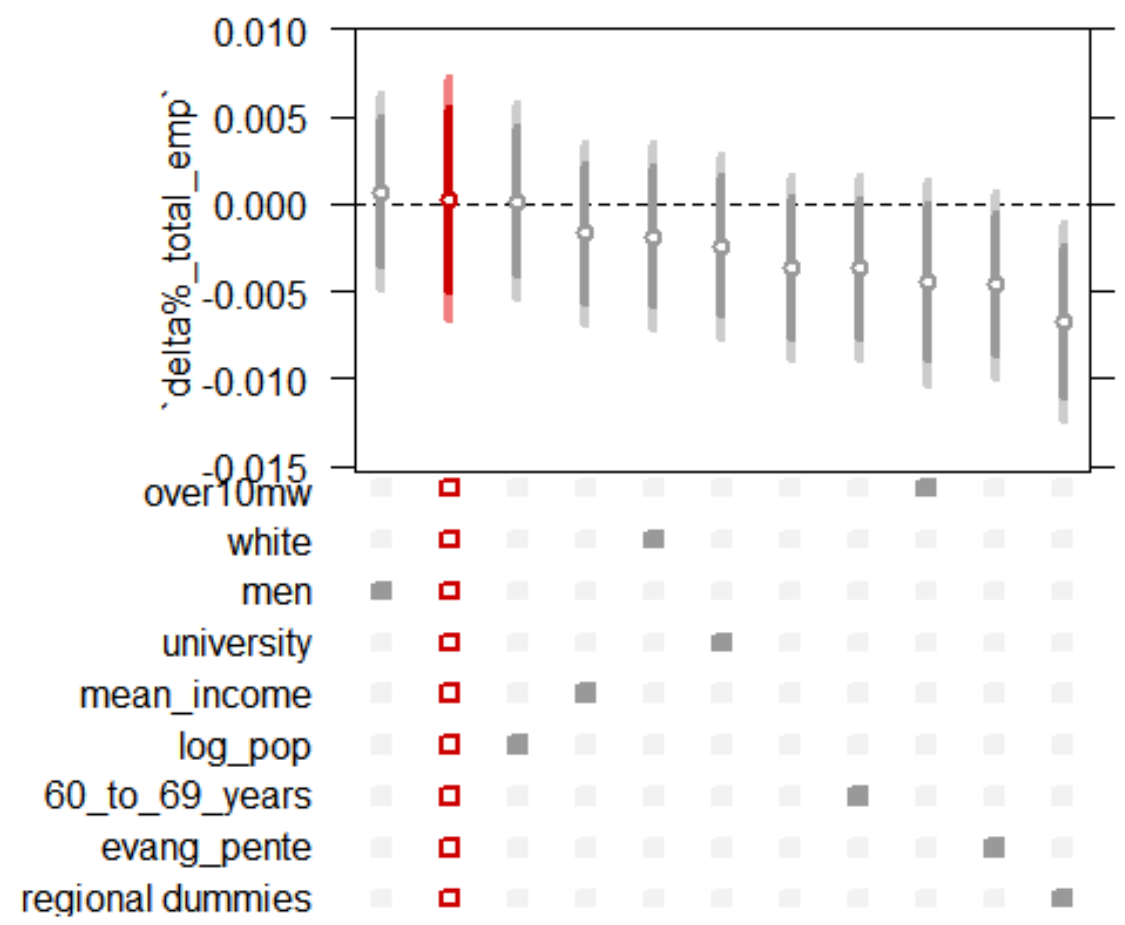

First of all, it is worth noting that the effect of $\mathrm{z}$ on the average wage of the commodity producing sectors is not significant in any of the specifications (Figure 2). Also, as can be seen in Figure 3, a commodity price shock does have a significant effect on the employment in commodity-producing sectors in all specifications, though the significance is slightly smaller when the only included control is the variable over10mw - share of a municipality's population that earn more than 10 mininum wages per month. Lastly, as Figure 4 shows, the effect of $\mathrm{z}$ on total employment is non-significant in most specifications, but is negative and significant when we only include the regional dummies. This is puzzling, because we would not expect that an increase in commodity prices could lead to a decrease in total employment. We hypothesize that this might be due to a shift from formal jobs to informal jobs in the commodity-producing sector, but our data does not allow us to test this hypothesis.

In light of these results, we've decided to use delta\%_emp, the percentage change in employment in commodity-producing sectors as our variable of interest in the secondstage equations. It is worth noting that this association between commodity prices and employment in commodity-producing sectors is a well-established fact in the literature on commodity booms (Álvarez, García-Marín and Ilabaca, 2021; Bayramoğlu, 2014; Pellandra, 2015), though some papers also find a relation between commodity booms and wages (Álvarez, García-Marín and Ilabaca, 2021) or wage inequality (Adão, 2015; Goderis and 
Malone, 2011). Some papers that explore the economic effects of a change in commodity prices are focused in its effect on GDP and/or the exchange rate (Ben Zeev, Pappa and Vicondoa, 2017; Collier and Goderis, 2012; Drechsel and Tenreyro, 2018; Kaminsky, Reinhart and Vegh, 2005), which we did not explore in this research.

\subsection{Second stage results}

Now that we have established a link between an exogenous commodity price shock and local employment in commodity-producing sectors, we look into the relationship between the job loss associated with a commodity price reduction and electoral outcomes in the 2018 presidential election. As we have discussed in section 3.2, the period 2014-2018 was characterized by a fall in the prices of most commodities produced and exported by Brazil, as well as a reduction in the employment in the commodity-producing sectors employment also fell in other sectors, but our first stage results suggest that we can't attribute this to commodity price shocks.

Given the results that we have presented in the previous section, the causal mechanism we propose is the following: a negative commodity price shock reduces employment in commodity production, which leads to political dissatisfaction amongst those workers that lost their jobs. Since most commodity prices fell from 2014 to 2018, municipalities more dependent on commodity production should show higher support for Jair Bolsonaro in the presidential election and/or a higher share of invalid votes.

Table 5 - IV Regressions - no controls

\begin{tabular}{|c|c|c|c|c|}
\hline & \multicolumn{4}{|c|}{ Dependent variable: } \\
\hline & votes_PSL_1 & votes_PSL_2 & invalid_votes_1 & invalid_votes_2 \\
\hline & $(1)$ & $(2)$ & $(3)$ & $(4)$ \\
\hline delta\%_emp & $\begin{array}{c}-0.00078^{* * *} \\
(0.00027)\end{array}$ & $\begin{array}{c}-0.00076^{* * *} \\
(0.00029)\end{array}$ & $\begin{array}{c}0.00014^{* * *} \\
(0.00005)\end{array}$ & $\begin{array}{l}-0.00003 \\
(0.00005)\end{array}$ \\
\hline Observations & 4,715 & 4,715 & 4,715 & 4,715 \\
\hline $\mathrm{R}^{2}$ & -1.37761 & -1.00771 & -2.04116 & -0.02541 \\
\hline Adjusted $\mathrm{R}^{2}$ & -1.37811 & -1.00814 & -2.04180 & -0.02563 \\
\hline Residual Std. Error & 0.25064 & 0.26212 & 0.04347 & 0.03508 \\
\hline
\end{tabular}

Note:

${ }^{*} \mathrm{p}<0.1 ;{ }^{* *} \mathrm{p}<0.05 ;{ }^{* * *} \mathrm{p}<0.01$

On Table 5, we report the estimated coefficient of delta\%_emp (instrumented by z) in some electoral outcomes from the 2018 election. In these regressions we did not include any control variables, and Table 5 omits the regressions' constants. As expected, 
the results suggest that the exogenous part of a decrease in commodity-producing sectors' employment is associated with an increase in the support for Bolsonaro in both rounds of the presidential election. A one-percent reduction in employment in commodity production is associated with an increase in Bolsonaro's share of votes: an additional 0.078 percentage point in the first round, and an additional 0.076 percentage point in the runoff.

The results also indicate that such employment reduction is associated with a reduction of 0.014 percentage point in the share of invalid votes in the first round, but has no significant effect on the share of invalid votes in the runoff. This suggests that instead of a job loss leading people to shun politics, they engage more in voting. It is interesting that this result only appears in the first round when there are more candidates, which increases the chance that an individual voter will feel represented by one of the available options.

However, our second stage results are not robust to the inclusion of controls. As can be seen in Figures 5 and 6, delta\%_emp (instrumented by z) has a small and negative association with the support for Bolsonaro in most specifications, with statistical significance falling in the $5 \%$ confidence interval, but not $1 \%$. When we include the share of self-declared pentecostal evangelicals, the effect isn't significant at any level.

This suggests that religiosity may explain a relevant part of the support for Bolsonaro. This provides a link to the literature that focuses on the cultural backlash approach to explain electorates' radicalization. Specifically, Inglehart and Norris (2016) also found that religious people were more likely to vote for anti-establishment politicians, though in a much different context.

Besides that, the percentage change in employment appears to have a positive association with support for Bolsonaro in both rounds when we only include the regional dummies as controls. Since the commodity-price shock is evidently unequally distributed throughout the regions (see Figure 1), it isn't surprising that including regional dummies change the results, though this change in the estimates' sign is puzzling. In order to investigate this, we have ran regressions (not included here, available upon request) on regional subsets of the sample but these are generally insignificant, which may be due to the reduction in the number of municipalities when we focus in each of the regions.

When it comes to the effect of commodity-trade induced job loss on the share of invalid votes, Figures 7 and 8 show that the effect is positive but only significant at the $5 \%$ level in most specifications. When we include the log of population or the share of men, the effect isn't significant even at the $5 \%$ level. It is interesting that controlling for population and the share of men makes the effect of job-loss on invalid votes disappear. As can be seen in Table 6, municipalities with more men show a lower share of invalid votes in both rounds, while more populous municipalities tend to have fewer invalid votes in both rounds. 
Figure 5 - Specification chart: effect of delta\%_emp on votes_PSL_1, 1 control

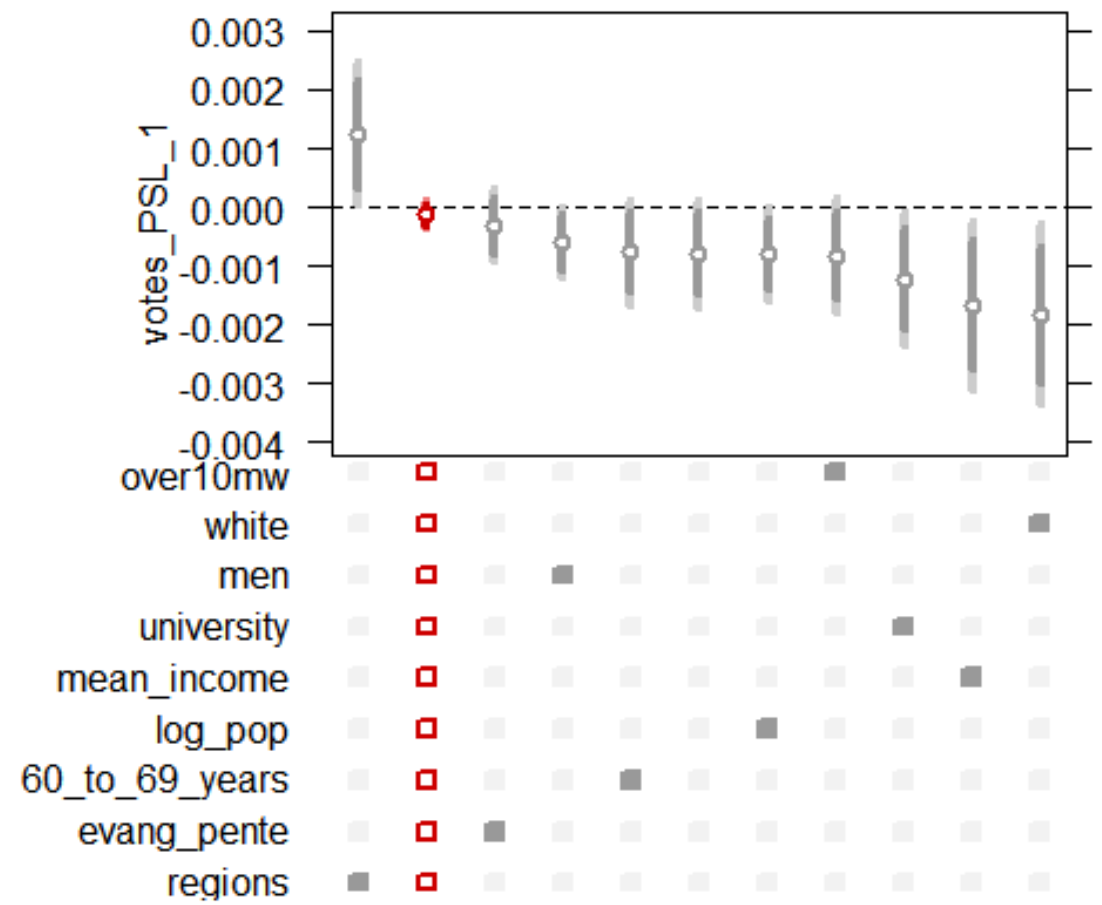

Figure 6 - Specification chart: effect of delta\%_emp on votes_PSL_2, 1 control

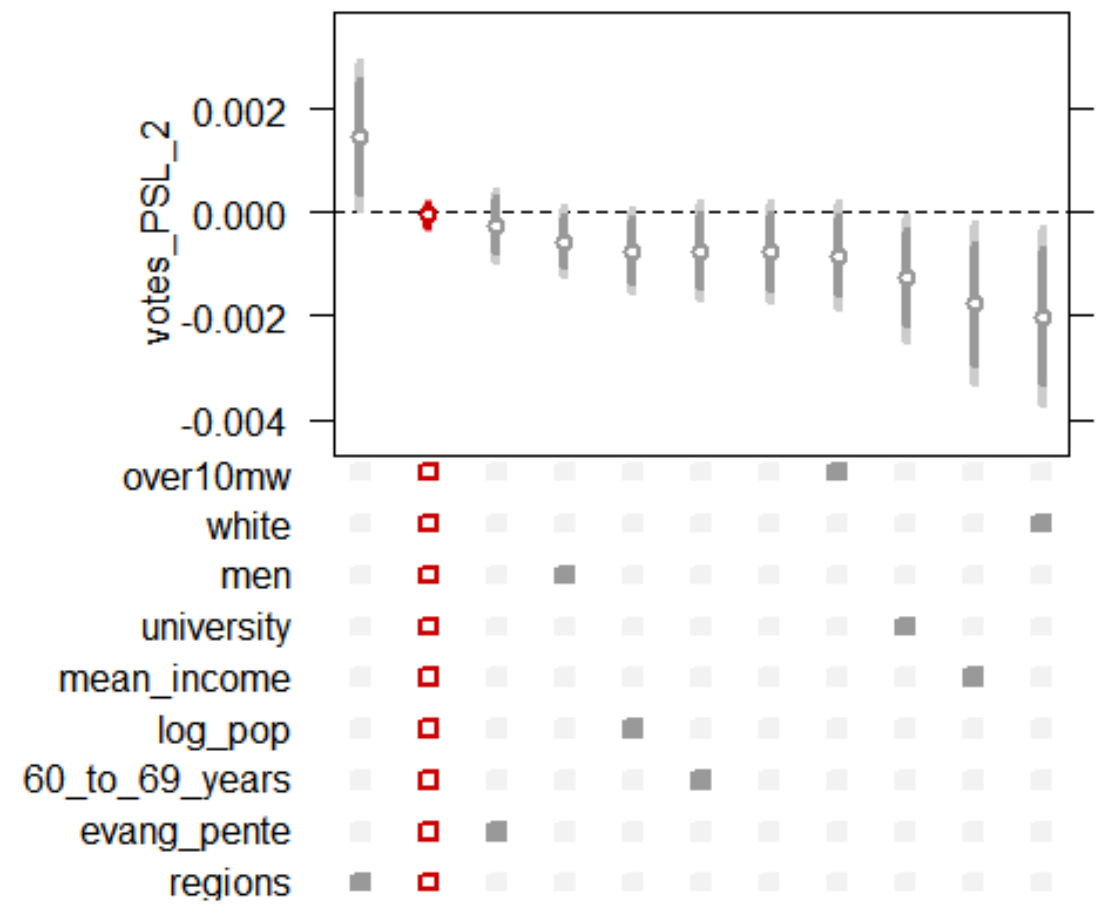


Figure 7 - Specification chart: effect of delta\%_emp on invalid_votes_1, 1 control

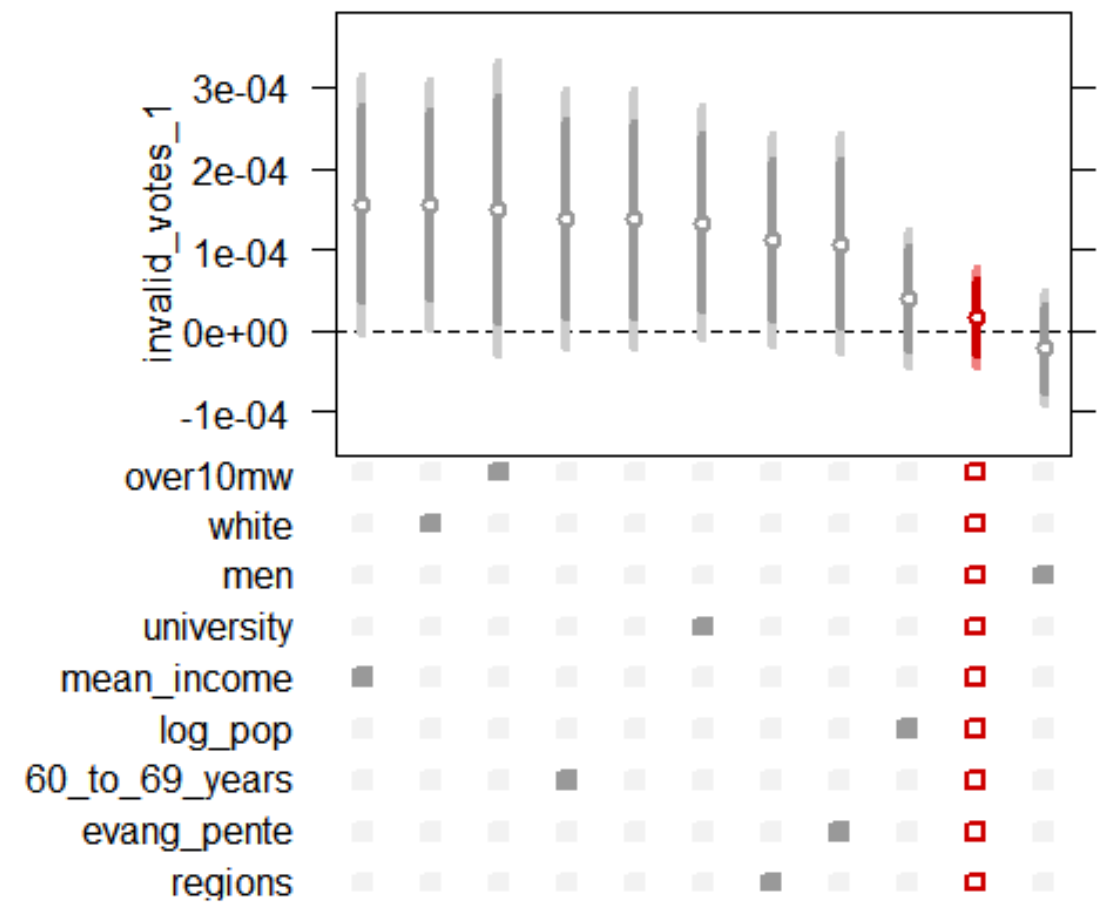

Figure 8 - Specification chart: effect of delta\%_emp on invalid_votes_2, 1 control

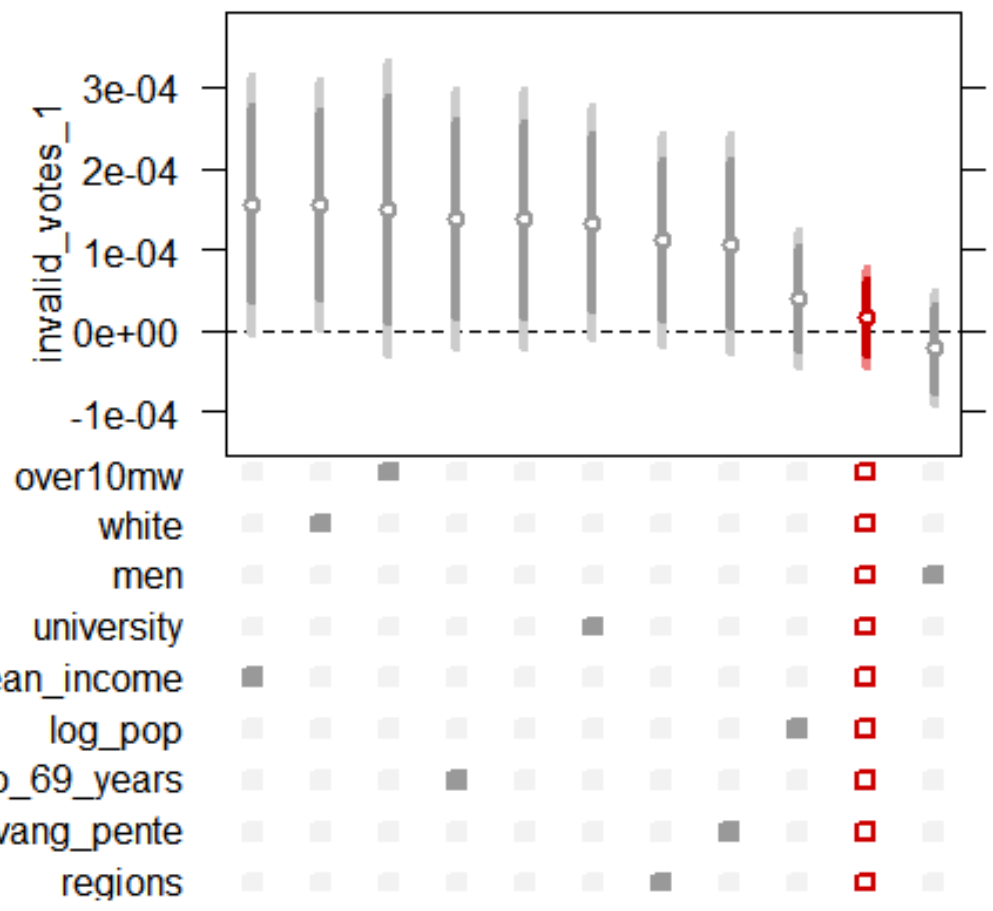


Table 6 provides the regression results of the models that include all controls. Most of the controls' coefficients go in the directions discussed by Nicolau (2020). For instance: all else constant, municipalities with higher shares of white people show more support for Bolsonaro in both rounds. Also, a higher share of college-educated or pentecostal evangelicals increases the support for Bolsonaro and decreases invalid votes.

However, some coefficients go in the opposite direction than we had expected. Municipalities with a higher share of older people or high-income families show lower support for Bolsonaro in both rounds, and a higher proportion of men is associated with less support for Bolsonaro in the first round. Here, it is worth noting that Nicolau (2020) works with individual-level poll data. His results indicate that a high-income individual is more likely to vote for Bolsonaro, while our results indicate that municipalities with many high-income families show lower support for Bolsonaro at the municipality level. Of course, this does not mean that these high-income families aren't themselves voting for Bolsonaro.

Finally, we look into the regional dummies. Here, the more populous Southeast is the baseline of comparison. All else constant, the results indicate that municipalities in the North or Midwest show higher support for Bolsonaro, while those in the Northeast or South show lower support. All four regions appear to have fewer invalid votes than the Southeast.

It's interesting that the inclusion of significant controls such as the mean income and the proportion of families that earn more than 10 minimum wages, the proportion of white people, men, the elderly, and college-educated people do not affect the significance of the estimated effect. This suggests that though these variables are relevant to explain the appeal of Bolsonaro's candidacy, they are not correlated with the commodity-induced formal labor market shock. 
Table 6 - IV Regressions - all controls

\begin{tabular}{|c|c|c|c|c|}
\hline & \multicolumn{4}{|c|}{ Dependent variable: } \\
\hline & $\begin{array}{c}\text { votes_PSL_1 } \\
\text { (1) }\end{array}$ & $\begin{array}{c}\text { votes_PSL_2 } \\
(2)\end{array}$ & $\begin{array}{c}\text { invalid_votes_1 } \\
\text { (3) }\end{array}$ & $\begin{array}{c}\text { invalid_votes_2 } \\
(4)\end{array}$ \\
\hline delta\%_emp & $\begin{array}{l}-0.00012 \\
(0.00010)\end{array}$ & $\begin{array}{l}-0.00005 \\
(0.00009)\end{array}$ & $\begin{array}{c}0.00002 \\
(0.00002)\end{array}$ & $\begin{array}{c}0.00003 \\
(0.00002)\end{array}$ \\
\hline over10mw & $\begin{array}{c}-5.58000^{* * *} \\
(0.52972)\end{array}$ & $\begin{array}{c}-6.40566^{* * *} \\
(0.50233)\end{array}$ & $\begin{array}{c}-0.62346^{* * *} \\
(0.11769)\end{array}$ & $\begin{array}{c}0.16928 \\
(0.11823)\end{array}$ \\
\hline white & $\begin{array}{c}0.28997^{* * *} \\
(0.01178)\end{array}$ & $\begin{array}{c}0.36394^{* * *} \\
(0.01237)\end{array}$ & $\begin{array}{l}0.00800^{* *} \\
(0.00321)\end{array}$ & $\begin{array}{c}0.01622^{* * *} \\
(0.00331)\end{array}$ \\
\hline men & $\begin{array}{c}-0.26588^{* *} \\
(0.13090)\end{array}$ & $\begin{array}{l}-0.10283 \\
(0.13507)\end{array}$ & $\begin{array}{c}-0.25615^{* * *} \\
(0.03556)\end{array}$ & $\begin{array}{c}-0.29938^{* * *} \\
(0.03582)\end{array}$ \\
\hline university & $\begin{array}{c}0.22162^{* * *} \\
(0.08379)\end{array}$ & $\begin{array}{c}0.33155^{* * *} \\
(0.08571)\end{array}$ & $\begin{array}{c}-0.05009^{* *} \\
(0.01957)\end{array}$ & $\begin{array}{c}-0.17118^{* * *} \\
(0.01895)\end{array}$ \\
\hline mean_income & $\begin{array}{c}0.00011^{* * *} \\
(0.00001)\end{array}$ & $\begin{array}{c}0.00012^{* * *} \\
(0.00001)\end{array}$ & $\begin{array}{c}-0.0000002 \\
(0.000001)\end{array}$ & $\begin{array}{c}-0.000003^{* *} \\
(0.000001)\end{array}$ \\
\hline $\log \_p o p$ & $\begin{array}{l}-0.00306 \\
(0.00191)\end{array}$ & $\begin{array}{l}-0.00157 \\
(0.00193)\end{array}$ & $\begin{array}{c}0.00263^{* * *} \\
(0.00049)\end{array}$ & $\begin{array}{c}0.00361^{* * *} \\
(0.00048)\end{array}$ \\
\hline 60_to_69_years & $\begin{array}{c}-0.55956^{* * *} \\
(0.13869)\end{array}$ & $\begin{array}{c}-0.57652^{* * *} \\
(0.14161)\end{array}$ & $\begin{array}{c}0.10534^{* * *} \\
(0.03218)\end{array}$ & $\begin{array}{c}0.09653^{* * *} \\
(0.03323)\end{array}$ \\
\hline evang_pente & $\begin{array}{c}0.41872^{* * *} \\
(0.02875)\end{array}$ & $\begin{array}{c}0.47059^{* * *} \\
(0.02989)\end{array}$ & $\begin{array}{c}-0.01837^{* * *} \\
(0.00711)\end{array}$ & $\begin{array}{c}-0.04339^{* * *} \\
(0.00706)\end{array}$ \\
\hline north & $\begin{array}{c}0.04947^{* * *} \\
(0.01074)\end{array}$ & $\begin{array}{c}0.03928^{* * *} \\
(0.01123)\end{array}$ & $\begin{array}{c}-0.02682^{* * *} \\
(0.00282)\end{array}$ & $\begin{array}{c}-0.04945^{* * *} \\
(0.00260)\end{array}$ \\
\hline northeast & $\begin{array}{c}-0.08788^{* * *} \\
(0.00599)\end{array}$ & $\begin{array}{c}-0.10984^{* * *} \\
(0.00594)\end{array}$ & $\begin{array}{c}-0.00723^{* * *} \\
(0.00165)\end{array}$ & $\begin{array}{c}-0.06320^{* * *} \\
(0.00176)\end{array}$ \\
\hline midwest & $\begin{array}{c}0.06902^{* * *} \\
(0.00490)\end{array}$ & $\begin{array}{c}0.06470^{* * *} \\
(0.00510)\end{array}$ & $\begin{array}{c}-0.01426^{* * *} \\
(0.00129)\end{array}$ & $\begin{array}{c}-0.05282^{* * *} \\
(0.00124)\end{array}$ \\
\hline south & $\begin{array}{c}-0.01625^{* * *} \\
(0.00419)\end{array}$ & $\begin{array}{c}-0.02873^{* * *} \\
(0.00451)\end{array}$ & $\begin{array}{c}-0.02934^{* * *} \\
(0.00104)\end{array}$ & $\begin{array}{c}-0.05719^{* * *} \\
(0.00107)\end{array}$ \\
\hline Constant & $\begin{array}{c}0.23965^{* * *} \\
(0.07971)\end{array}$ & $\begin{array}{l}0.17081^{* *} \\
(0.08277)\end{array}$ & $\begin{array}{c}0.19748^{* * *} \\
(0.02155)\end{array}$ & $\begin{array}{c}0.24663^{* * *} \\
(0.02202)\end{array}$ \\
\hline Observations & 3,679 & 3,679 & 3,679 & 3,679 \\
\hline $\mathrm{R}^{2}$ & 0.71517 & 0.78047 & 0.27074 & 0.58127 \\
\hline Adjusted $\mathrm{R}^{2}$ & 0.71416 & 0.77969 & 0.26816 & 0.57979 \\
\hline Residual Std. Error & 0.08425 & 0.08394 & 0.02119 & 0.02178 \\
\hline
\end{tabular}

Note:

${ }^{*} \mathrm{p}<0.1 ;{ }^{* *} \mathrm{p}<0.05 ;{ }^{* * *} \mathrm{p}<0.01$ 


\subsection{Reduced form results}

Now we turn to the reduced form estimates that investigate the direct effect of a commodity price shock on electoral outcomes, without mediation by the formal labor market. Table 7 show the estimated coefficient of $\mathrm{z}$ when we do not include any control variable (we omit the constant). The direction and significance of the estimates do not change much from what we reported on Table 5: a negative price shock is associated with an increase in the support for Bolsonaro in both rounds. It is also associated with a decrease in the share of invalid votes in the first round, but not in the runoff.

Table 7 - RF Regressions - no controls

\begin{tabular}{lcccc}
\hline \hline & \multicolumn{4}{c}{ Dependent variable: } \\
\cline { 2 - 5 } & votes_PSL_1 & votes_PSL_2 & invalid_votes_1 & invalid_votes_2 \\
& $(1)$ & $(2)$ & $(3)$ & $(4)$ \\
\hline $\mathrm{z}$ & $\left(0.00003^{* * *}\right.$ & $-0.00003^{* * *}$ & $0.00001^{* * *}$ & -0.000001 \\
& & $(0.00001)$ & $(0.000001)$ & $(0.000002)$ \\
\hline Observations & 4,715 & & & \\
$\mathrm{R}^{2}$ & 0.00247 & 0.00182 & 0.00324 & 4,715 \\
Adjusted R & 0.00226 & 0.00161 & 0.00303 & -0.00007 \\
Residual Std. Error & 0.16235 & 0.18482 & 0.02489 & 0.03464 \\
F Statistic & $11.67878^{* * *}$ & $8.58851^{* * *}$ & $15.31510^{* * *}$ & 0.32990 \\
\hline \hline Note: & & & ${ }^{*} \mathrm{p}<0.1 ;{ }^{* *} \mathrm{p}<0.05 ;{ }^{* * *} \mathrm{p}<0.01$
\end{tabular}

However, the reduced form estimates are way more robust to the inclusion of controls than the second stage estimates. As can be seen in Figures 9 and 10, a positive price shock has a negative and significant (at the 1\% level) effect on support for Bolsonaro in most specifications. The estimates lose significance when we include the share of selfdeclared pentecostal evangelicals, and the direction of the effect changes when we only include the regional dummies.

The improved robustness of the reduced form estimates suggests that the effect of a commodity price shock is also felt in some way that is not reflected in formal employment - for instance, changes in informal employment might be more important. Also, as was the case with the second stage estimates, the loss of significance when we include the share of evangelicals highlights the importance of religiosity in the 2018 presidential election. The fact that the estimates' sign change when we only include the regional dummies is due to the fact that the price shocks were felt unequally across the country's regions, as can be seen in Figure 1. 
Figure 9 - Specification chart: direct effect of $\mathrm{z}$ on votes_PSL_1, 1 control

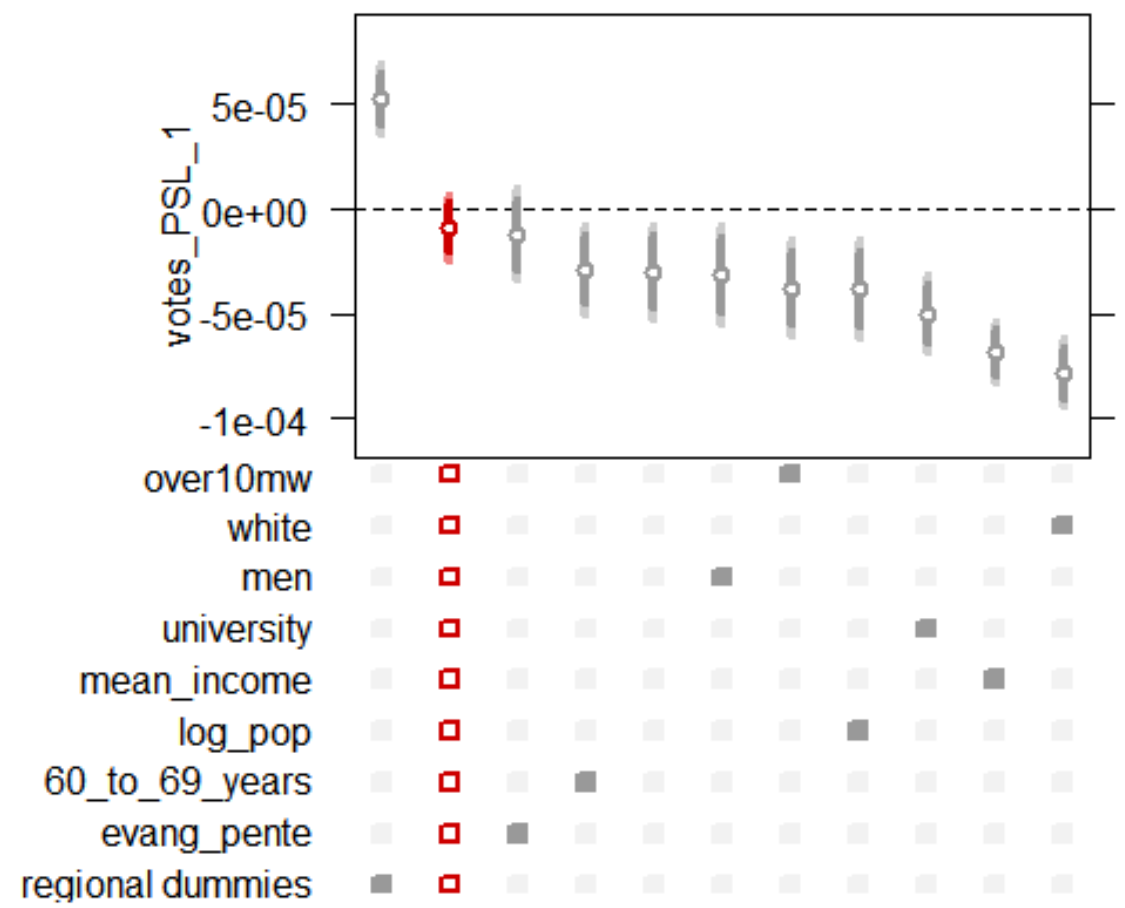

Figure 10 - Specification chart: direct effect of $\mathrm{z}$ on votes_PSL_2, 1 control

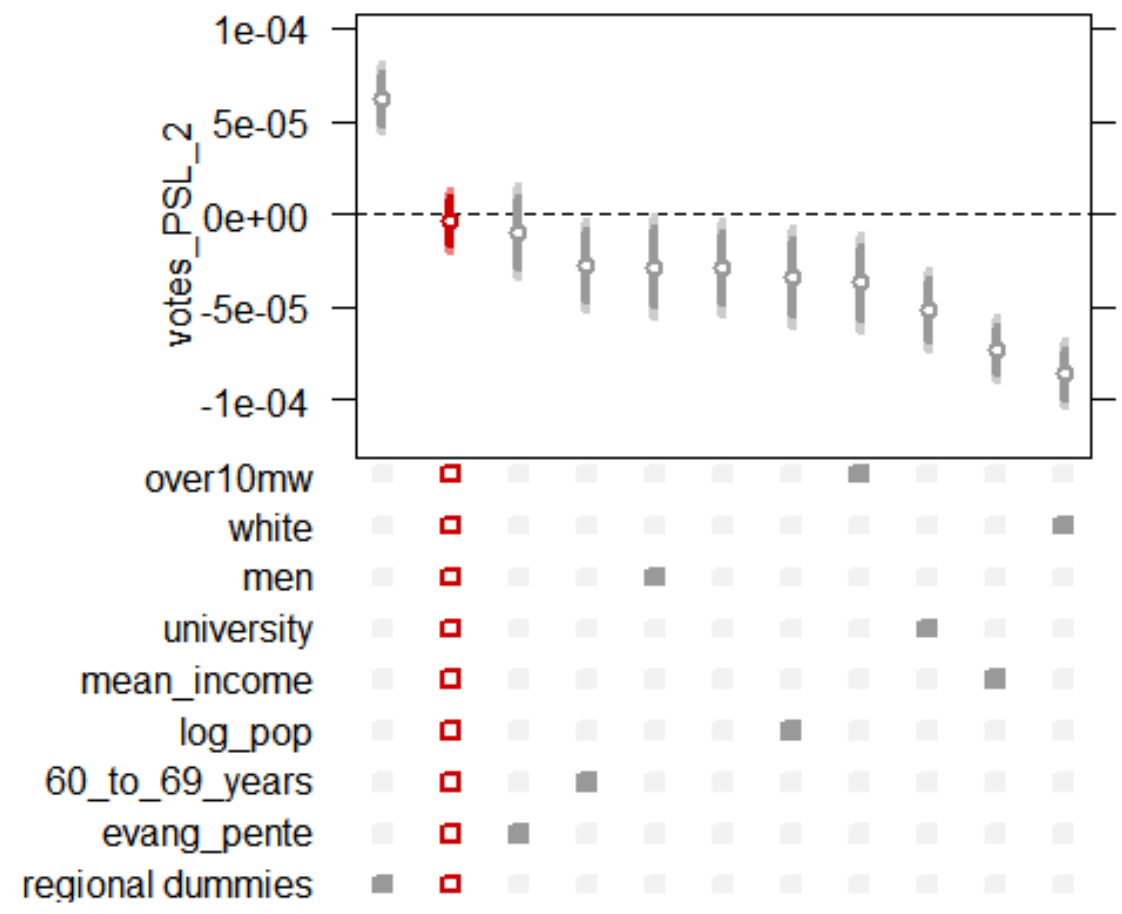


Figure 11 - Specification chart: direct effect of $\mathrm{z}$ on invalid_votes_1, 1 control

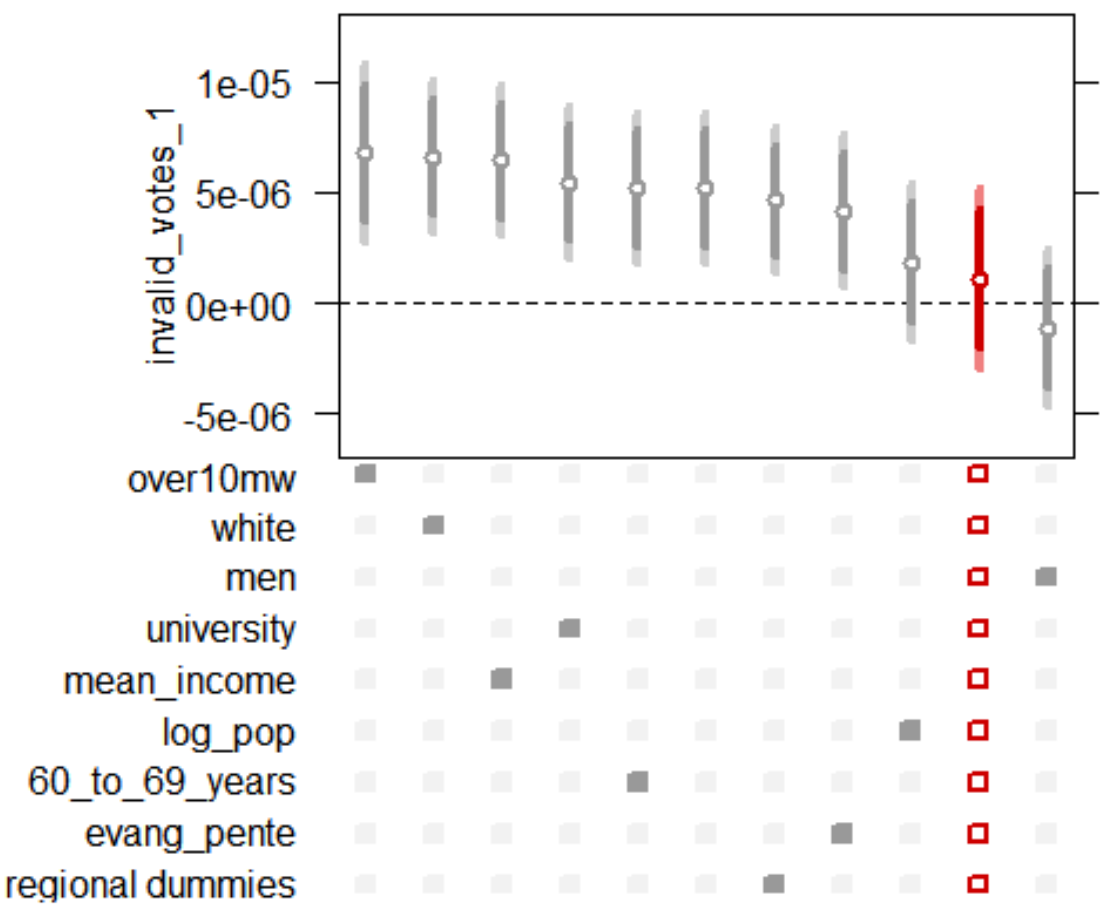

Figure 12 - Specification chart: direct effect of $\mathrm{z}$ on invalid_votes_2, 1 control

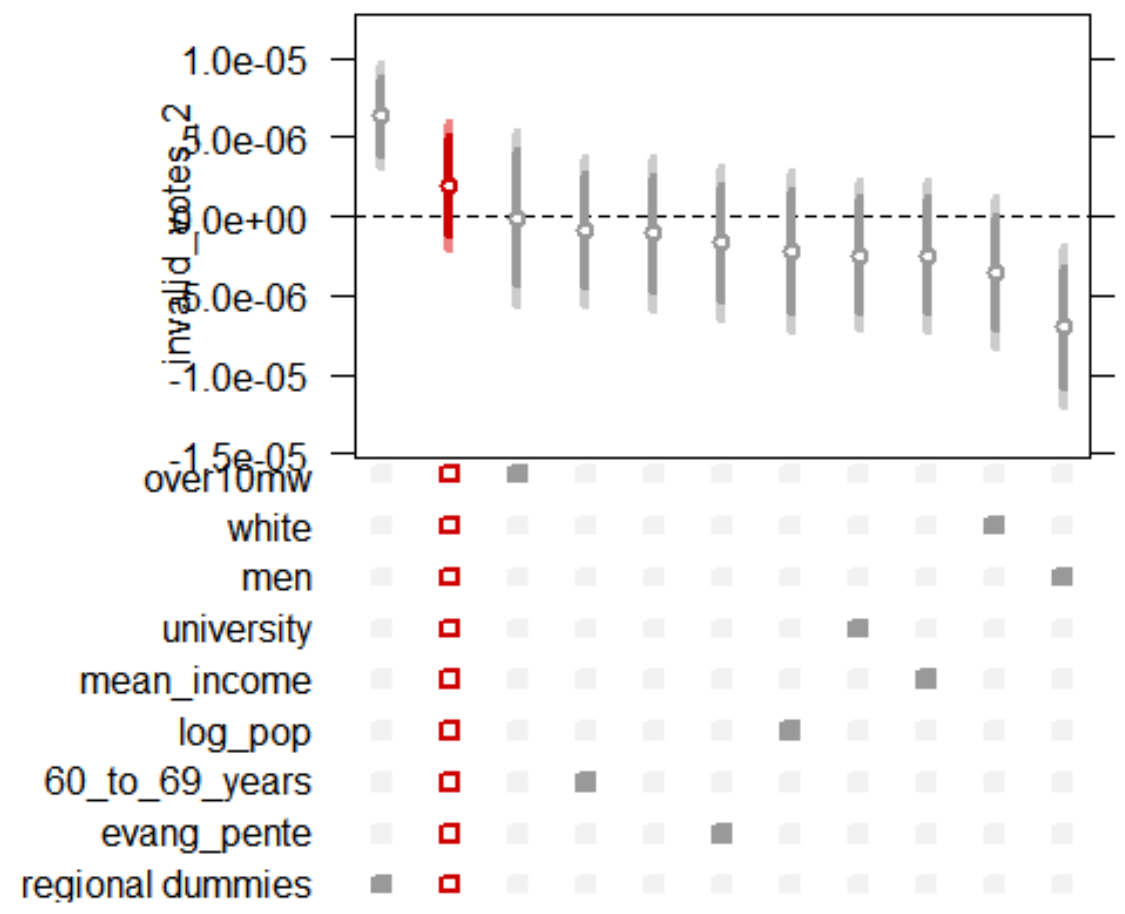


When we look at the specification charts for the effect of $\mathrm{z}$ on the share of invalid votes in the first round (Figure 11), we can see that the effect of $\mathrm{z}$ is positive and significant at the $1 \%$ level in most specifications. It loses significance when we include the log of population, and changes direction (though not significantly) when we include the share of men. The effect of $z$ on the share of invalid votes in the second round (Figure 12) is negative but not significant at any level in most specifications. It is negative and significant when we only take into account the share of men, and it is positive and significant when we only take into account the regional dummies.

Though we do not report the estimated coefficients of the regressions that include all controls, as we did for the second stage results in Table 6, it is worth mentioning that the direction and significance of nearly all estimates is the same of Table 6 , so that the discussion we have made on section 4.2 still holds: support for Bolsonaro increases with the share of white people, pentecostal evangelicals, people with higher education, and decreases with the share of older people, men and high-income families.

\section{Conclusions}

Using the sectoral composition of employment to measure a municipality's exposure to shocks in the international commodity trade, we were able to investigate the effect of the fall in commodity prices in 2014-2018 on the election of Jair Bolsonaro in 2018. We established that the fall in commodity prices is associated with a fall in formal jobs in commodity-producing sectors throughout Brazil, which is in consonance with the literature on commodity booms and busts (Álvarez, García-Marín and Ilabaca, 2021).

Building upon this result, we show that the formal job loss associated with a decrease in commodity prices does increase support for Bolsonaro both in the first-round and in the runoff of the 2018 presidential election, which contributes to a growing literature on the effect of international trade shocks on the support for anti-establishment politicans, such as Autor et al. (2020), Colantone and Stanig (2018a) and Dippel, Gold and Heblich (2015). Our reduced form results, which do not take into account the mediation of a shock through the labor market, also go in that direction.

However, the significance of our estimates disappears when we include the share of self-declared pentecostal evangelicals, which suggests that religiosity may explain a relevant part of the support for Bolsonaro. It is important to note that the share of evangelicals in each municipality's population is measured in 2010, so it can't be endogenous to the subsequent crisis. The fact that high shares of evangelicals are associated with higher 
support for Bolsonaro is in consonance of the findings of Inglehart and Norris (2016) on the support of the religious for populist candidates in Western Europe, and also confirms the findings of Nicolau (2020) that support for Bolsonaro was higher amongst pentecostal evangelicals. Our results add to the evidence on the interaction between economic and cultural factors in explaining the support for far-right politicians. We are not aware of papers that empirically assess the importance of the evangelical vote in the 2018 election, though the relation between the rise of evangelical politicians and support for Bolsonaro is analyzed by Almeida (2019).

When we look into the share of invalid votes, we find an association between a negative trade shock and a decrease in the share of invalid votes in the first round of the presidential election. This association does not appear to be present in the runoff. This is interesting both because there are more candidates in the first round, and because it differs from the evidence that in the USA contexts of economic crises increase voter abstention (Green and McElwee, 2019). Voting is mandatory in Brazil, but based on this literature we expected that the crisis would increase the number of null votes.

Our findings contribute to the larger literature on the effects of international trade conditions on the support for anti-establishment politicians and provide new insight into how the recent crisis - or, at least, the commodity-trade-induced part of the crisis - fostered support for a radical right anti-establishment candidate in the Brazilian presidential election of 2018. In future work, we intend to expand this investigation by looking into the effect of the commodity price shocks through the informal market. In order to do so, we will incorporate data from the National Household Sample Survey (Pesquisa Nacional por Amostra de Domicílios, PNAD), a quarterly household survey conducted by the Brazilian Statistical Agency, IBGE. Though the use of data from PNAD does not allow us to include all of the country's municipalities, the results from the subsample of municipalities covered by PNAD may help us uncover why the inclusion of regional dummies alters our main results, given that Census data indicates that municipalities outside the Southeast tend to have more workers in informality. 


\section{Bibliography}

ADÃO, R. Worker heterogeneity, wage inequality, and international trade: theory and evidence from Brazil. Mimeo: Massachusetts Institute of Technology, 2015. Disponível em: < http://economics.mit.edu/files/11145>. Acesso em: 25 maio 2021.

ALABRESE, E.; BECKER, S.; FETZER, T.; NOVY, D. Who voted for Brexit? Individual and regional data combined. European Journal of Political Economy, v. 56, p. 132-150, 2019.

ALMEIDA, R. Bolsonaro presidente - conservadorismo, evangelismo e a crise brasileira. Novos Estudos Cebrap, v. 38, n. 1, p. 185-213, 2019.

ÁLVAREZ, R.; GARCÍA-MARÍN, A.; ILABACA, S. Commodity price shocks and poverty reduction in Chile. Resources Policy, v. 70, p. 101-177, 2021.

AMOROZO, M.; KOS, C.; MOREIRA, R. Em evento sobre pandemia, Bolsonaro defende cloroquina e critica jornalistas. CNN Brasil, 24 ago. 2020. Disponível em: < https://www.c nnbrasil.com.br/politica/2020/08/24/bolsonaro-cita-infeccoes-em-ministros-e-volta-a-defen der-hidroxicloroquina>. Acesso em: 25 maio 2021.

ARNORSSON, A.; ZOEGA, G. On the causes of Brexit. European Journal of Political Economy, v. 55, p. 301-323, 2018.

AUTOR, D.; DORN, D.; HANSON, G.; MAJLESI, K. Importing political polarization? The electoral consequences of rising trade exposure. American Economic Review, v. 110, n. 10, p. 3139-3183, 2020.

BARROS, L.; SANTOS SILVA, M. Ele não: Economic crisis, the political gender gap, and the election of Bolsonaro. In: VfS Annual Conference 2020 (Virtual Conference): Gender Economics, Proceedings, Verein für Socialpolitik / German Economic Association. Disponível em: <https://ideas.repec.org/p/zbw/vfsc20/224632.html>. Acesso em: 25 maio 2021.

BAYRAMOĞLU, A. The impact of agricultural commodity price increases on agricul- 
tural employment in Turkey. Procedia - Social and Behavioral Sciences, v. 143, p. 1058-1063, 2014.

BECKER, S.; FETZER, T.; NOVY, D. Who voted for Brexit? A comprehensive districtlevel analysis. Economic Policy, v. 32, p. 601-650, 2017.

BEN-ZEEV, N.; PAPPA, E.; VICONDOA, A. Emerging economies business cycles: the role of commodity terms of trade news. Journal of International Economics, v. 108, p. $368-376,2017$.

CAMPELLO, D.; ZUCCO, C. Presidential success and the world economy. The Journal of Politics, v. 78, n. 2, 2016.

CARRERAS, M.; CARRERAS, Y.; BOWLER, S. Long-term economic distress, cultural backlash, and support for Brexit. Comparative Political Studies, v. 52, n. 9, p. 1396-1424, 2019.

CAVAILLE, C.; FERWERDA, J. How distributional conflict over public spending drives support for anti-immigrant parties. CAGE Working Paper Series, n. 328, 2017.

CNN Brasil. Bolsonaro entra com ação no STF contra restrições de governadores do DF, BA e RS. 19 mar. 2021. Disponível em: <https://www.cnnbrasil.com.br/politica/ 2021/03/19/bolsonaro-entra-com-acao-no-stf-contra-restricoes-de-governadores-do-df-ba-ers>. Acesso em: 25 maio 2021.

COLANTONE, I.; STANIG, P. The trade origins of economic nationalism: import competition and voting behavior in Western Europe. American Journal of Political Science, v. 62 , n. 4, p. 936-953, 2018a.

COLANTOnE, I.; STANIG, P. Global competition and Brexit. American Political Science Review, v. 112, n. 12, p. 201-218, 2018b.

COLLIER, P.; GODERIS, B. Commodity prices and growth: an empirical investigation. European Economic Review, v. 56, p. 1241-1260, 2012.

COMITÊ DE DATAÇÃO DE CICLOS ECONÔMICOS. Comunicado de Datação de 
Ciclos Mensais Brasileiros. Rio de Janeiro: FGV: CODACE, out. 2017. Disponível em: $<$ https://portal

ibre.fgv.br/sites/default/files/2020-03/comite-de-data_o-de-ciclos-econ_micos-comunicadode-

30_10_2017-_1_.pdf $>$. Acesso em: 25 maio 2021.

DAMÉ, L. Taxa de abstenção na eleição presidencial é a maior desde 1998. Agência Brasil, 28 out. 2018. Disponível em: <https://agenciabrasil.ebc.com.br/politica/noticia/201810/taxa-de-abstencao-na-eleicao-presidencial-e-maior-desde-1998>. Acesso em: 06 junho 2021.

DEHDARI, S. Economic distress and support for far-right parties - evidence from Sweden. Mimeo: Institute for International Economics Studies - Stockholm University, 2018. Disponível em: <https://conpol.org/wp-content/uploads/2019/12/EconomicDis tress.pdf $>$. Acesso em: 25 maio 2021.

DIPPEL, C.; GOLD, R.; HEBLICH, S. Globalization and its (dis-)content: trade shocks and voting behavior. NBER Working Paper Series, n. 21812, 2015.

DRECHSEL, T.; TENREYRO, S. Commodity booms and busts in emerging economies. Journal of International Economics, v. 112, p. 200-218, 2018.

FETZER, T. Did austerity cause Brexit? American Economic Review, v. 109, n. 11, p.3849-3886, 2019.

FRASER, B. How anti-science attitudes have impacted the coronavirus pandemic in Brazil. Scientific American, 27 maio 2020. Disponível em: <https://www.scientificamerican.co $\mathrm{m} /$ article/how-anti-science-attitudes-have-impacted-the-coronavirus-pandemic-in-brazil/?u tm_medium $=$ socialutm _ content $=$ organicutm_source $=$ twitterutm_campaign $=$ SciAm_sf $234435838=1>$. Acesso em: 25 maio 2021.

FRIEDMAN, U. The coronavirus-denial movement now has a leader. The Atlantic, 27 mar. 2020. Disponível em: <https://www.theatlantic.com/politics/archive/2020/03/bolson aro-coronavirus-denial-brazil-trump/608926/> . Acesso em: 25 maio 2021.

G1. Pesquisa Datafolha de 4 de outubro para presidente por sexo, idade, escolaridade, renda, região, religião e raça. 05 out. 2018. Disponível em: < https://g1.globo 
.com/politica/eleicoes/2018/eleicao-em-numeros/noticia/2018/10/05/pesquisa-datafolhade-4-de-outubro-para-presidente-por-sexo-idade-escolaridade-renda-regiao-religiao-e-raca.g html>. Acesso em: 06 junho 2021.

GIDRON, N.; MIJS, J. Do changes in material circumstances drive support for populist radical parties? Panel data evidence from the Netherlands during the Great Recession, 2007-2015. European Sociological Review, v. 35, n. 5, p. 635-650, 2019.

GODERIS, B.; MALONE, S. Natural resource booms and inequality: theory and evidence. The Scandinavian Journal of Economics, v. 113, n. 2, p. 388-417, 2011.

GREEN, J.; MCELWEE, S. The differential effects of economic conditions and racial attitudes in the election of Donald Trump. Perspectives on Politics, v. 17, p. 358-379, 2019.

HUNTER, W.; POWER, T. Bolsonaro and Brazil's illiberal backlash. Journal of Democracy, v. 30, n. 1, p. 68-82, 2019.

INGLEHART, R.; NORRIS, P. Trump, Brexit and the rise of populism: economic have-nots and cultural backlash. Harvard Kennedy School Working Paper Series, n. 16-026, 2016.

KAMINSKY, G.; REINHART, C.; VÉGH, C. When it rains, it pours: procyclical capital flows and macroeconomic policies. NBER Working Paper Series, n. 10780, 2004. Disponível em: <https://www.nber.org/papers/w10780>. Acesso em: 25 maio 2021.

MCKEE, M.; GUGUSHVILI, A.; KOLTAI, J.; STUCKLER, D. Are populist leaders creating the conditions for the spread of COVID-19?; Comment on "A scoping review of populist radical right parties' influence on welfare policy and its implications for population health in Europe", International Journal of Health Policy and Management, 2020. Disponível em: <https://www.ijhpm.com/article_3856.html>. Acesso em: 25 maio 2021.

MUIS, J.; IMMERZEEL, T. Causes and consequences of the rise of populist radical right parties and movements in Europe. Current Sociology Review, v. 65, n. 6, p. 909-930, 2017.

NICOLAU, J. O Brasil dobrou à direita: uma radiografia da eleição de Bolsonaro em 
2018. São Paulo: Zahar, 2020.

NOVAES, L.; SHIUMERINI, L. Exogenous commodity shocks and the electoral returns to office: evidence from Brazil. In: Anais do XLIII Encontro Nacional de Economia, ANPECAssociação Nacional dos Centros de Pós-Graduação em Economia, 2015. Disponível em: $<$ https://www.anpec.org.br/encontro/2015/submissao/files_I/i5-36850bc2ed0a5bfd1cd089 $8 \mathrm{~d} 24$

65ae6a.pdf >. Acesso em: 25 maio 2021.

PELLANDRA, A. The commodity price boom and regional workers in chile: a natural resources blessing? Mimeo: Heinz College, Carnegie Mellon University, 2015. Disponível em: <https://www.semanticscholar.org/paper/The-Commodity-Price-Boom-and-RegionalWorkers-in-a-Pellandra/5ecf4f0764da5971bbccc66bb1a8ed8731055fa6>. Acesso em: 25 maio 2021.

PEREIRA, E.; RIBEIRO, L.; FREITAS, L.; PEREIRA, H. Brazilian policy and agribusiness damage the Amazon rainforest. Land Use Policy, v. 92, 2020.

QUADROS, M.; MADEIRA, R. Fim da direita envergonhada? Atuação da bancada evangélica e da bancada da bala e os caminhos da representação do conservadorismo no Brasil. Opinião Pública, v. 24, n. 3, p. 486-522, 2018.

RINALDI, C.; BEKKER, M. A scoping review of populist radical right parties' influence on welfare policy and its implications for population health in Europe. International Journal of Health Policy and Management, v. 10, n. 3, p. 141-151, 2021.

ROSSI, M. Bolsonaro diz que sua candidatura é "imbroxável" e que "a Amazônia não é nossa". El País, 18 maio 2018. Disponível em: <https://brasil.elpais.com/brasil/2018/05/1 8/politica/152661

2140_988427.html>. Acesso em: 25 maio 2021.

TRIBUNAL SUPERIOR ELEITORAL. Estatísticas Eleitorais. Brasília: TSE, 2018. Disponível em: <http://www.tse.jus.br/eleicoes/estatisticas/estatisticas-eleitorais>. Acesso em: 25 maio 2021.

VIDIGAL, C.; BERNAL-MEZA, R. Bolsonaro versus Rio Branco: transição hegemônica, América do Sul e política externa. Revista de Relaciones Internacionales, Estrate- 
gia y Seguridad, v. 15, n. 2, p. 11-26, 2020.

WALLACE, S. Bolsonaro prometeu explorar os recursos da Amazônia - mas ele pode fazer isso? National Geographic, 31 out. 2018. Atualizado em 5 nov. 2020. Disponível em: $<$ https://www.nationalgeographicbrasil.com/meio-ambiente/2018/10/bolsonaro-exploracaominerios-agricultura-pecuaria-amazonia-povos-indigenas>. Acesso em: 25 maio 2021. 


\section{APPENDIX A - Commodity price trajectories, 2010-2018}

Graphs present price (red), value (blue) and amount exported in kilograms (green). All values are in indices (first year $=100$ ). For nearly all commodities, the first observed year is 2010 .

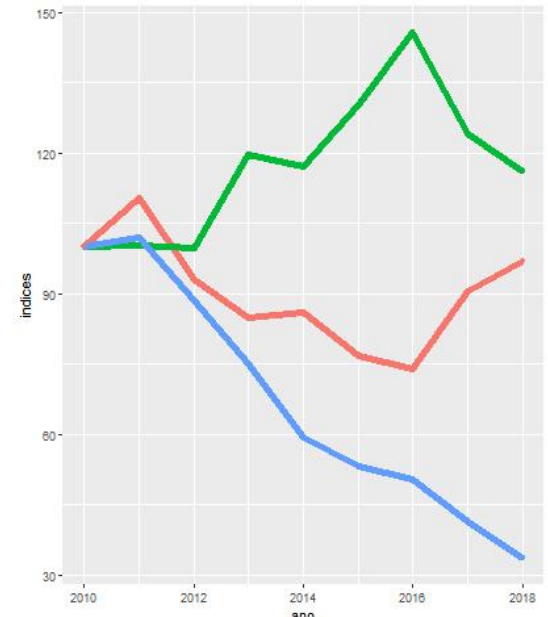

(a) Aluminum

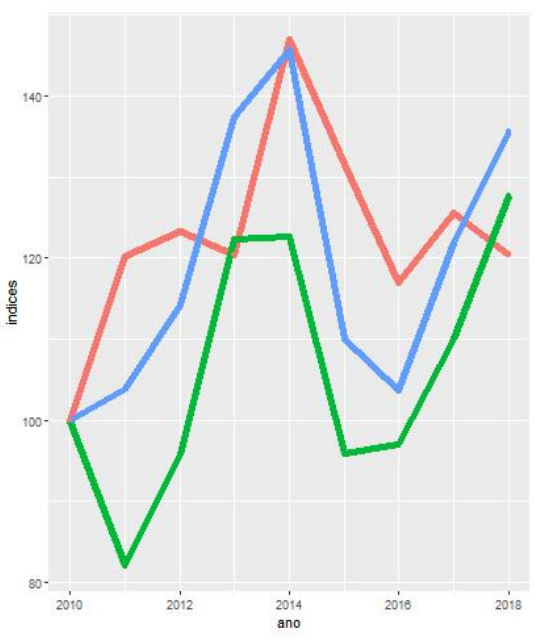

(c) Beef

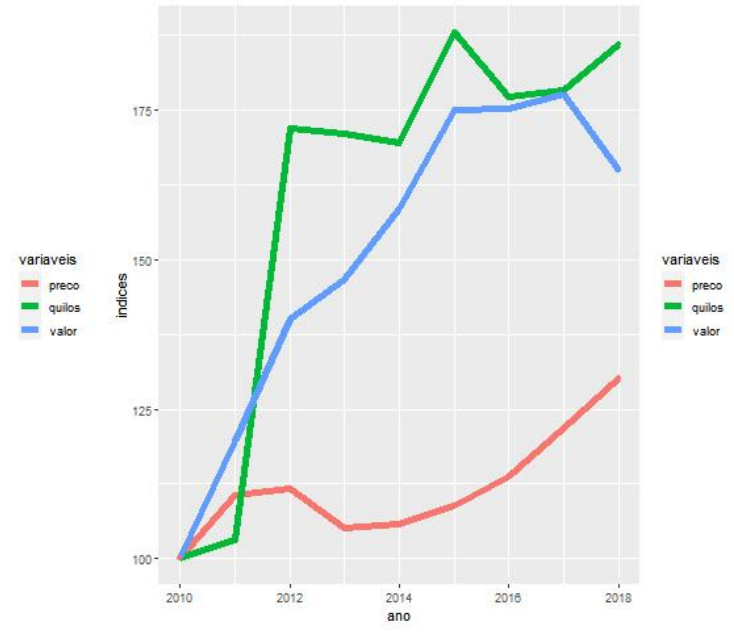

(b) Bananas

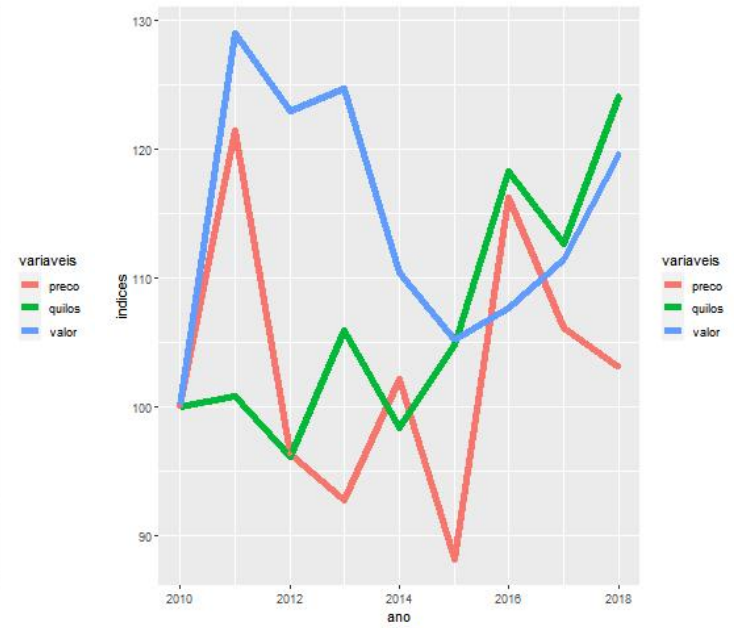

(d) Citrus Fruit + Orange Juice 


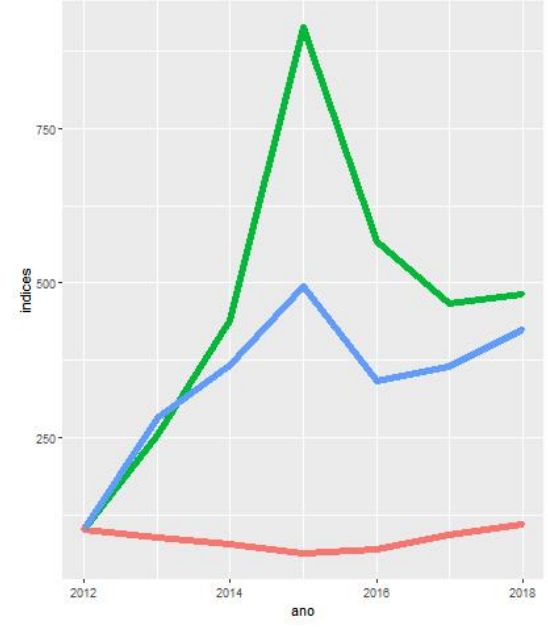

(a) Coal

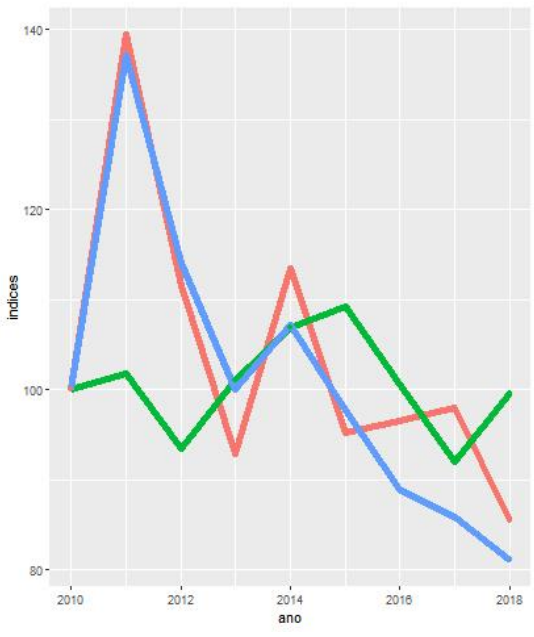

(c) Coffee

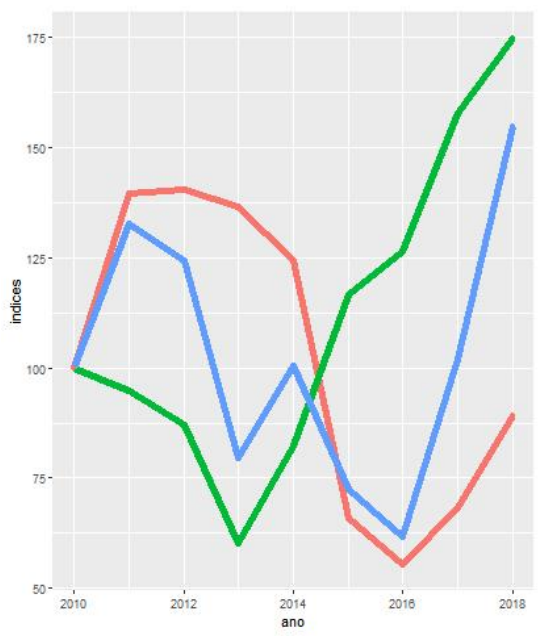

(e) Crude oil

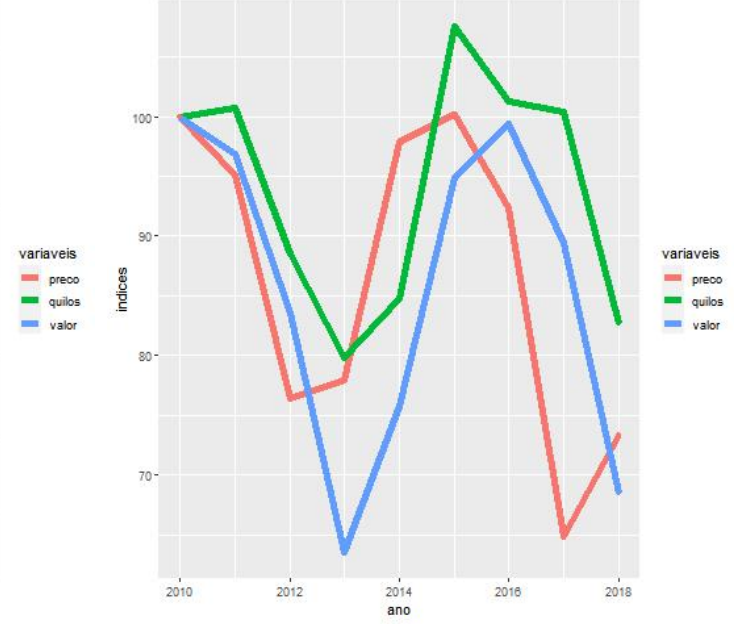

(b) Cocoa

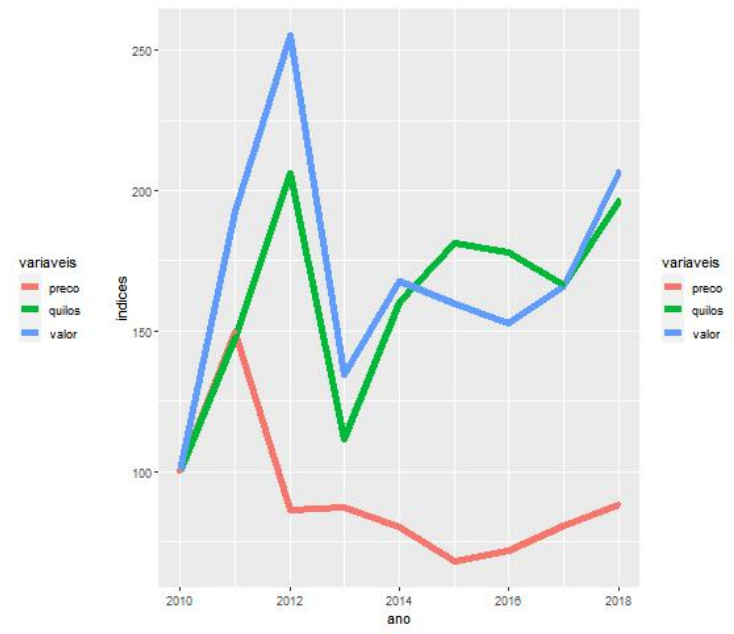

(d) Cotton

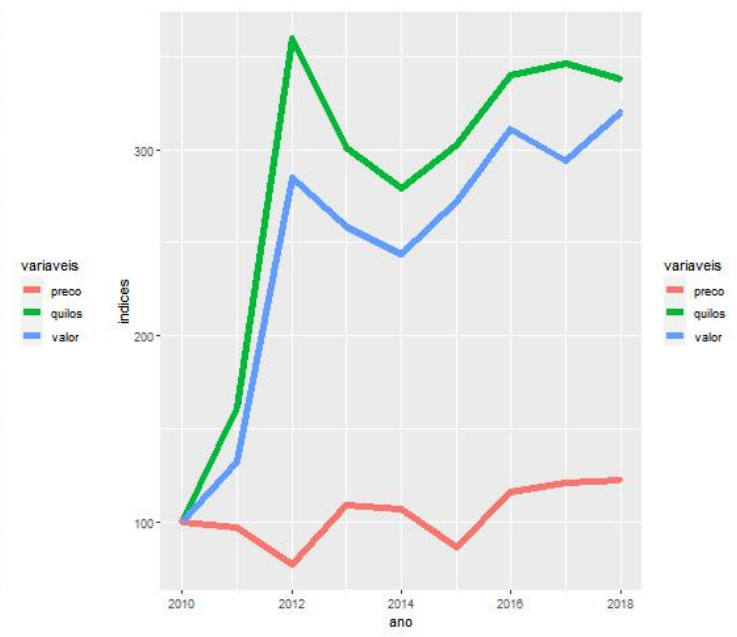

(f) Fish 


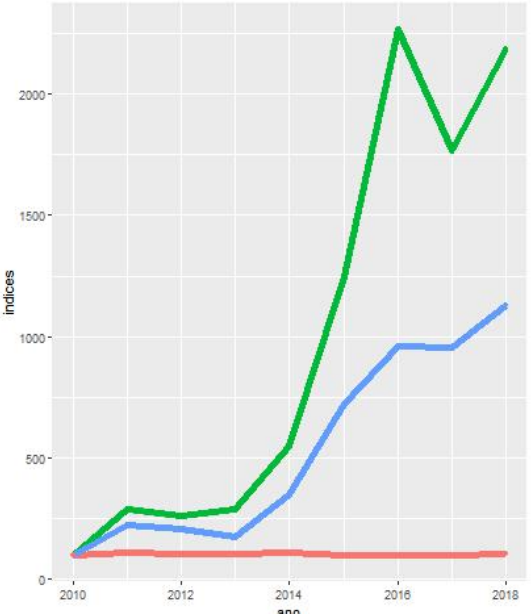

(a) Hardwood logs

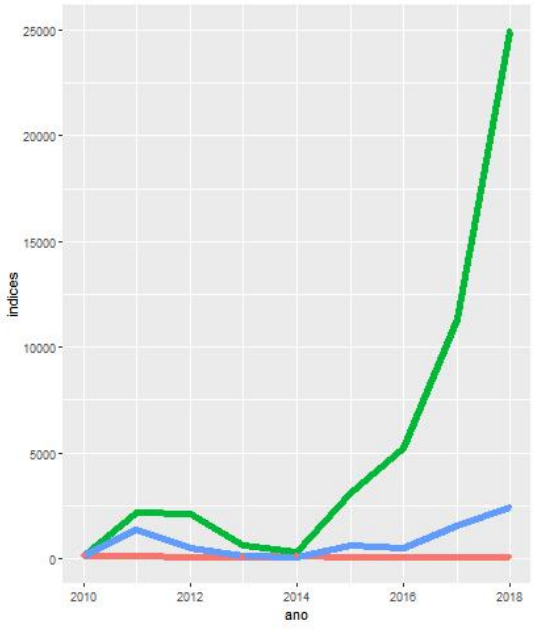

(c) Lamb

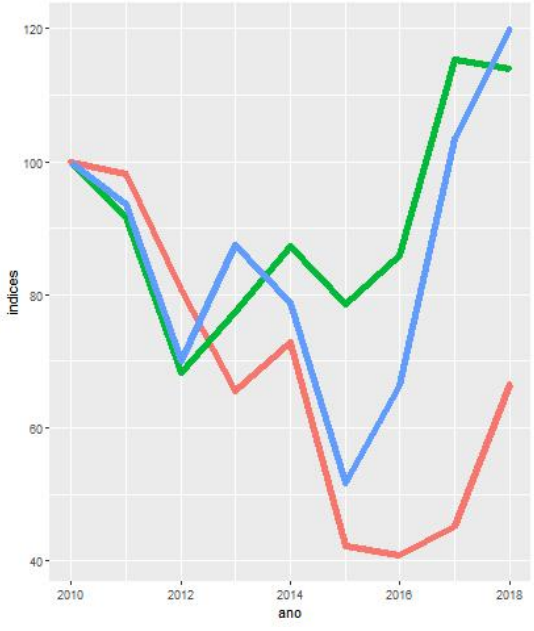

(e) Molybdenum

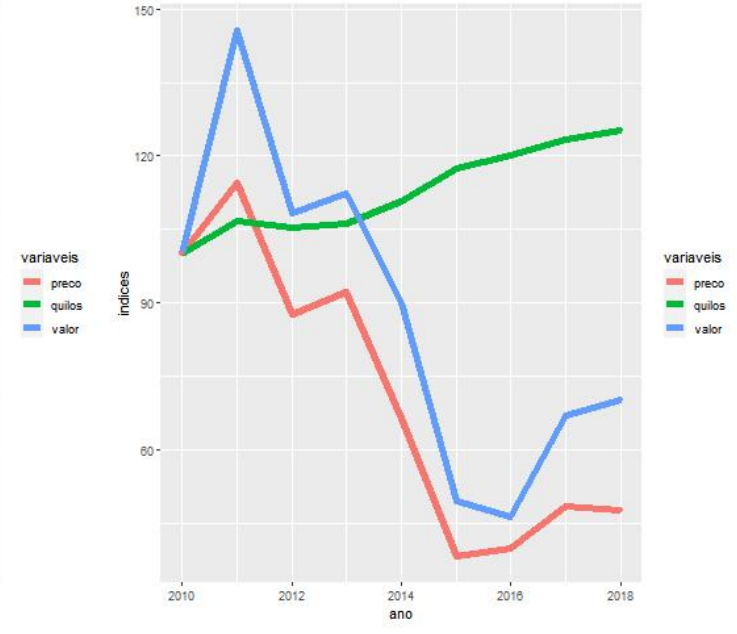

(b) Iron ore

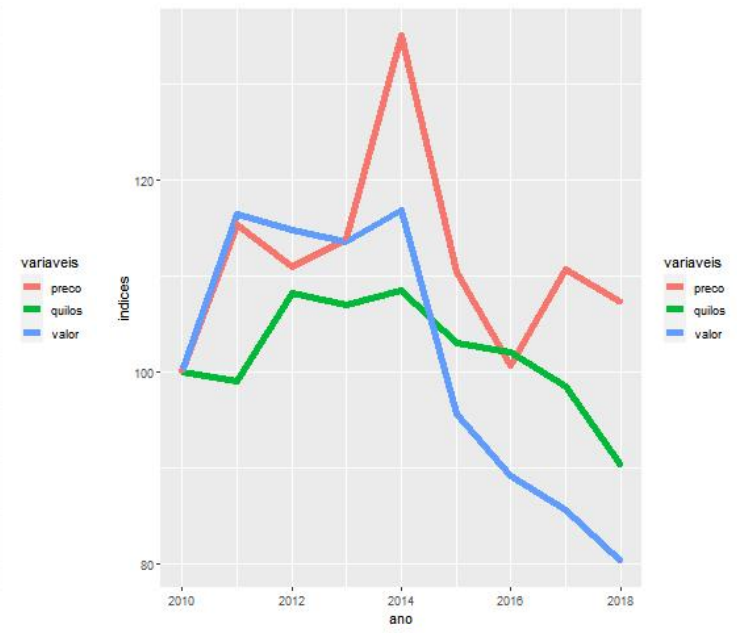

(d) Meat - DISTRIB

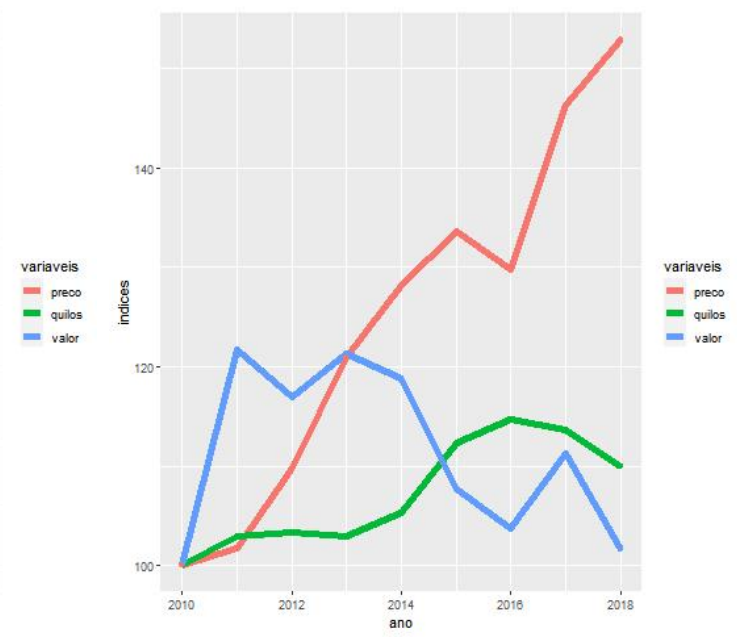

(f) Poultry 


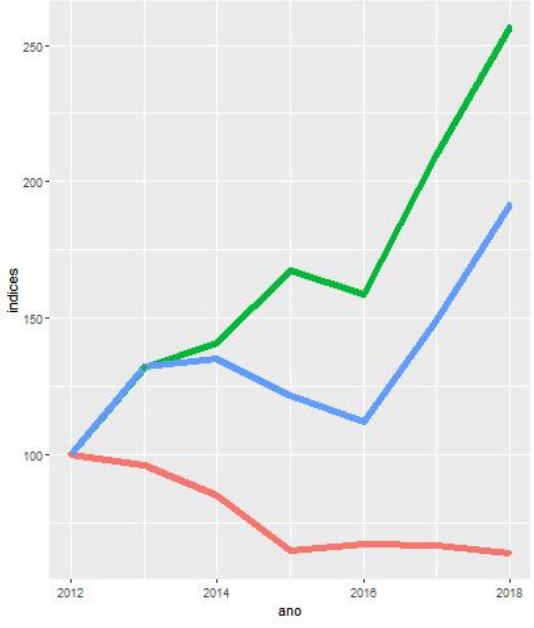

(a) Soybeans

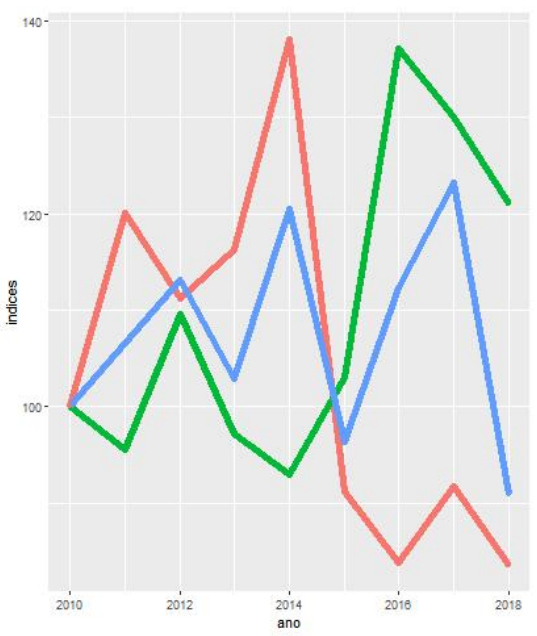

(c) Swine (Pork)

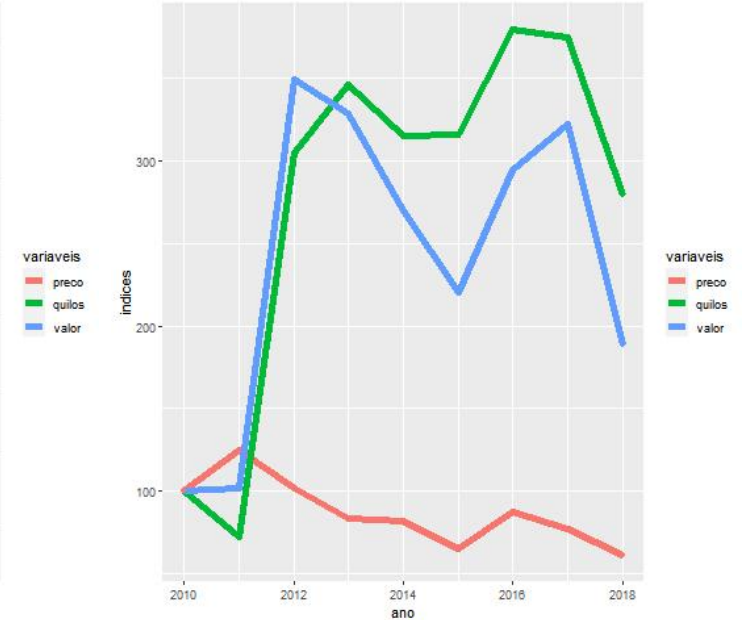

(b) Sugar

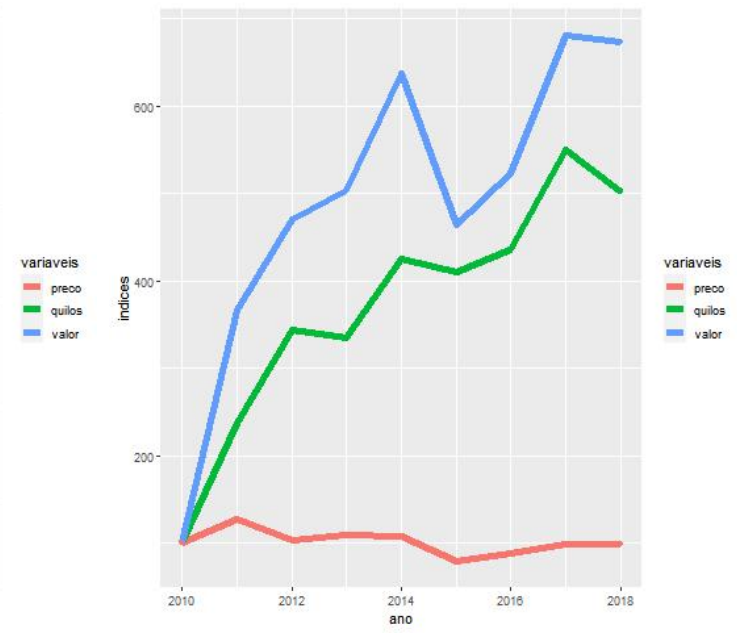

(d) Tin

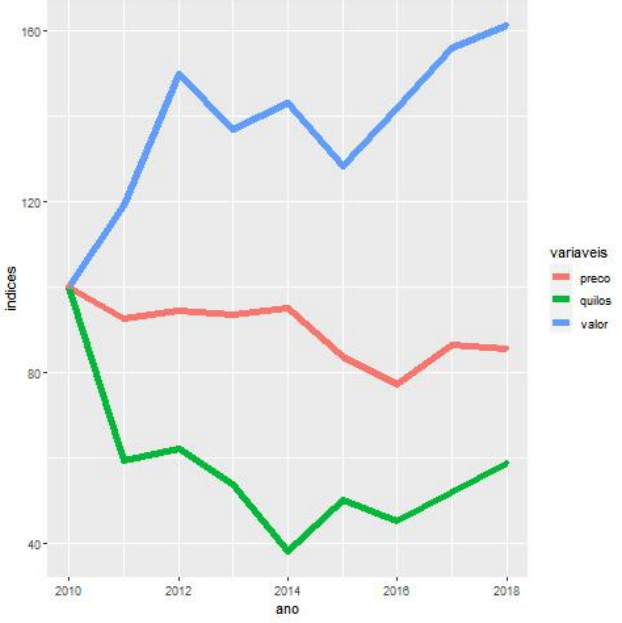

(e) Vegetables (Tomato) 


\section{APPENDIX B - Spatial visualization of election results}

Figure 17 - Spatial distribution of Bolsonaro's votes, first round 2018

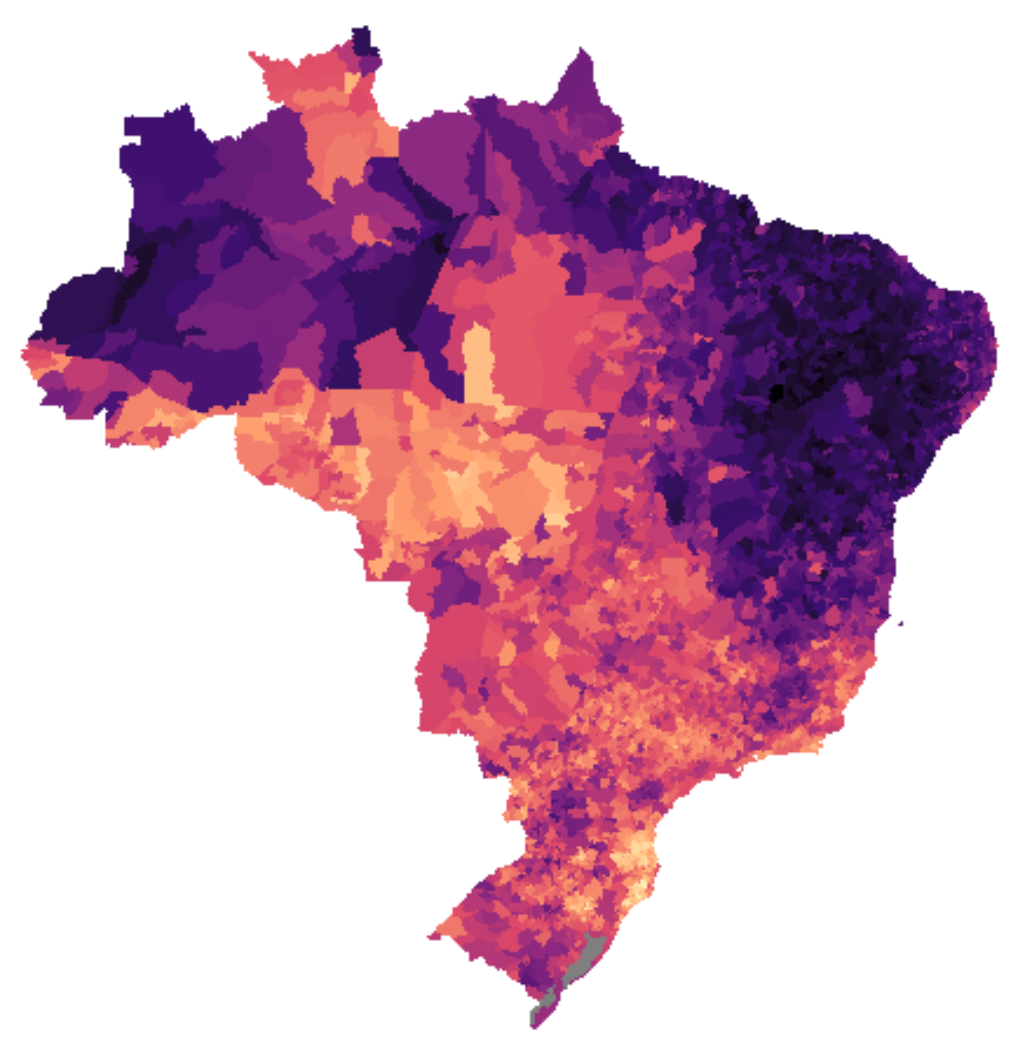

votes_PSL_1 
Figure 18 - Spatial distribution of Bolsonaro's votes, 2018 runoff

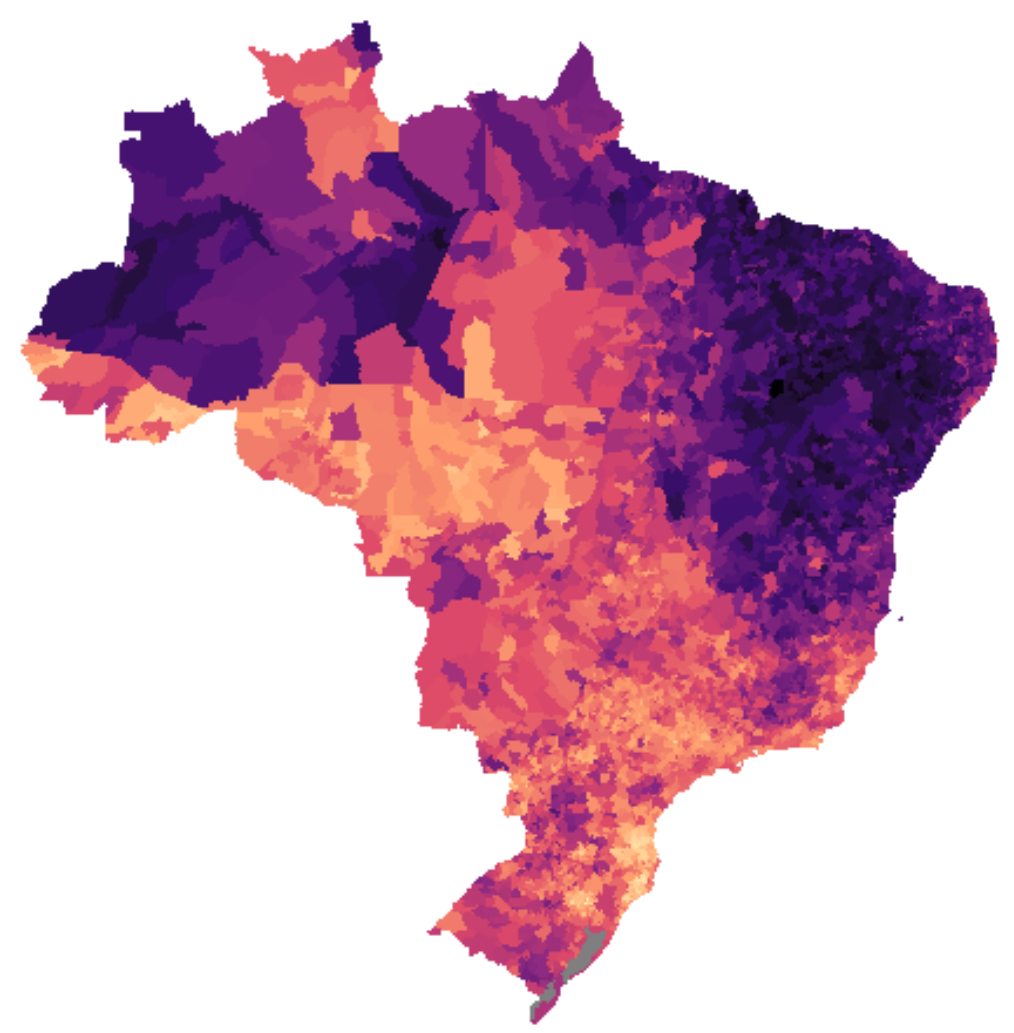

votes_PSL_2

0.8
-0.6
-0.4
-0.2 
Figure 19 - Spatial distribution of invalid votes, first round 2018

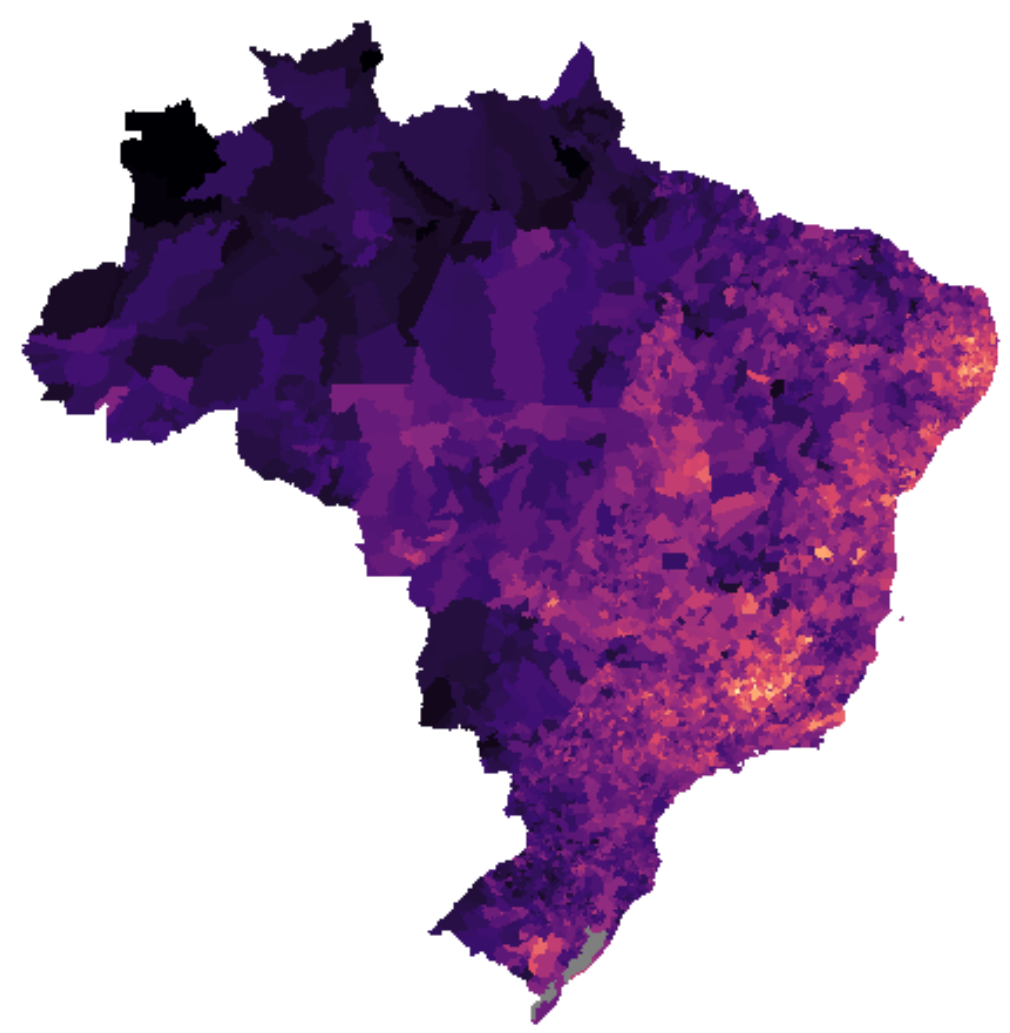

invalid_votes_1

0.15

0.10

0.05 
Figure 20 - Spatial distribution of invalid votes, 2018 runoff

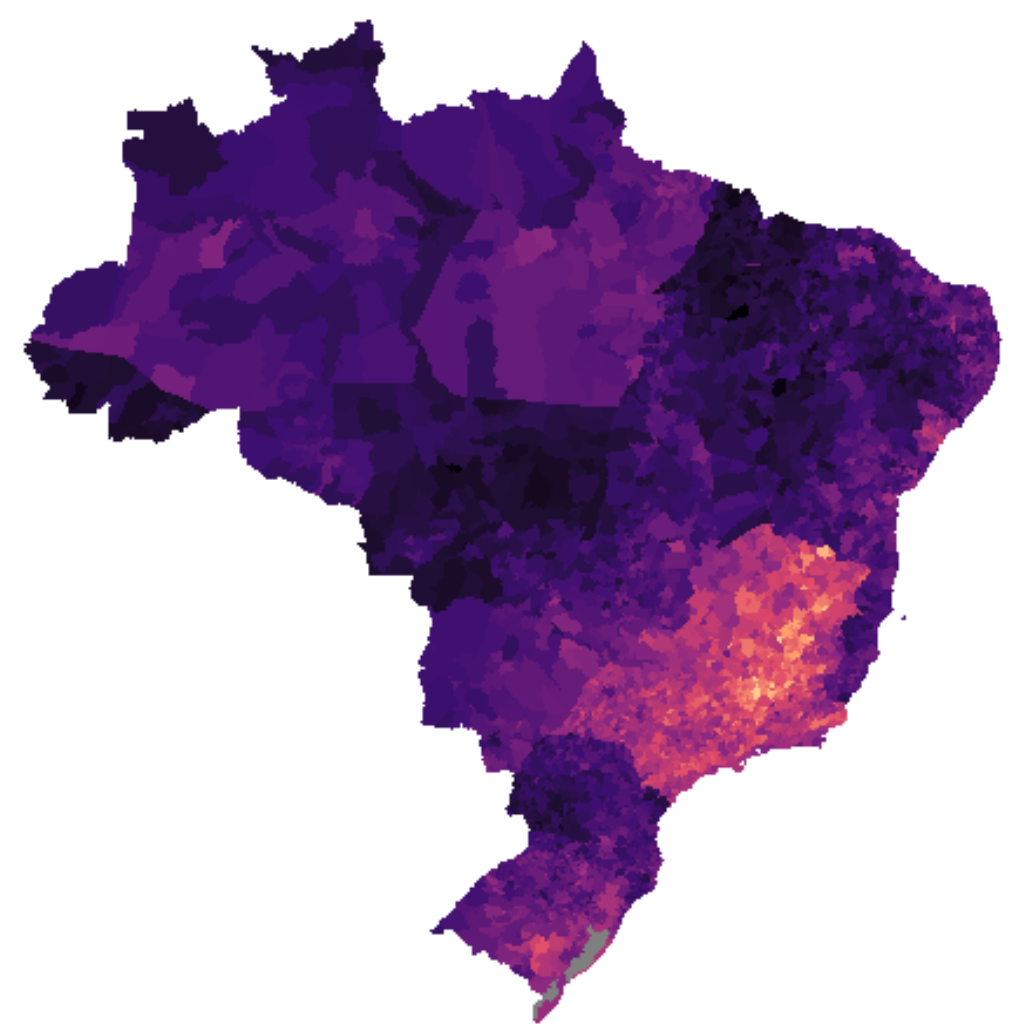

invalid_votes_2

0.20
-0.15
-0.10
-0.05

